\title{
Race, Culture, Identity: Misunderstood
}

Connections

\author{
K. ANTHONY APPIAH
}

The Tanner Lectures on Human Values

Delivered at

University of California at San Diego

October 27 and 28, 1994 
K. Anthony Appiah is professor of Afro-American studies at Harvard University. He was educated at Clare College and received his Ph.D. in philosophy from Cambridge University. He has been president of the Society for African Philosophy in North America and is an editor of Transition. He is a member of the African Literature Association, the American Philosophical Association, the Aristotelian Society, and the Modern Language Association, among others, and has been both a Woodrow Wilson Fellow and an Andrew W. Mellon Fellow. His numerous publications include Assertion and Conditionals (1985), For Truth in Semantics (1986), Necessary Questions: An Introduction to Philosophy (1989), and In My Father's House (1992), which won the Annisfield-Wolf Book Award and the Herskovits Award. He has also published a series of mystery novels, of which the most recent is Another Death in Venice, and is preparing, with his mother Peggy Appiah, a volume of about 7,000 translated proverbs from Asante in Ghana. 


\section{Part I. Analysis: Against Races}

\subsection{Explaining Race-thinking}

Imagine yourself on Angel Island in the 1920s. You are helping an inquisitive immigrant from Canton to fill in an immigration form. Name, it says. You ask her name. She tells you. You write it down. Date of birth. She gives it to you (according to the Chinese calendar, of course, so you have to look up your table for translating from one system to another). Then there is an entry that says Race. This you do not have to ask. You write: "Oriental." And your interlocutor, because she is inquisitive, asks politely: "What are you writing now?" (After all, until now, everything you have written has been in response to her answers.)

Disingenuously, you say: "I am writing down where you are from."

"Ah yes," she replies helpfully. "Canton, I was born in Canton. How did you know?"

"No. Actually, that's the next question I was going to ask. Place of birth."

"So what have you written already?"

How do you answer this question? Seventy years ago, how would you have explained to someone from outside the modern West what our English word "race" meant? Or how would you have explained to a Sicilian across the continent on Ellis Island,

Apart from specific debts to work cited, I should like to express my sense of enormous indebtedness to Lawrence Blum, Jorge Garcia, Martha Minow, Richard T. Ford, Maneesha Sinha, David Wilkins, and David Wong, for discussions both together and separately; to Houston Baker and Lucius Outlaw for prompting me to rethink these issues; to many people, whose names I have not recorded, to whom I have talked about identity and culture at many universities during the last few years; to several generations of students in my Introduction to Afro-American Studies class at Harvard; and, above all, to Henry Finder, on whom I try out most of my ideas first. 
thirty years earlier, why the right answer for him was "Caucasian"? (Where he came from, the people of the north of Italy, the ancestors of the modern Lombard league, think of him, as he very well knows, as of a different, darker, razza than theirs: how do you explain that here he is going to become white?) And would you give the same explanation today?

Or, again, imagine yourself in North Carolina, in the later nineteenth century, as Reconstruction is coming to an end. You are in a small town, out of the way, where there are families that come in all shades of skin color, milk through chocolate. A message comes through from the state capitol in Raleigh. Everyone now has to be white or colored. If you're white, step this way; colored, go the other. You are talking to Joe, a teenager, whose skin is milky white, whose eyes are blue, but whose grandmother, Mary, is a brown-skinned woman, who remembers her mother's stories of Africa. "I was gonna go with my grandma," he tells you. "But then I saw my Uncle Jim was gonna be with her, so I'm gonna cross to the other side of the room. 'Cos one thing I know for sure; I don't want to be anywhere my Uncle Jim's gonna be." '

Is Joe making a conceptual mistake? Or is he unintentionally making what will turn out to be a lucky choice for him and his descendants; a choice that will leave him and them with a vote, better schools, better jobs? Can you imagine someone like Joe, in the nineteenth-century South, born after emancipation but raised before the high-water mark of the strange career of Jim Crow, who doesn't know that in America, or at least in the Carolinas, even white-skinned people with black grandmothers are Negroes?

My preliminary aim in this essay is to explore the concept of race that is at work in these cases - an American concept, though also, of course, one that draws on and interacts with ideas from elsewhere. I will go on to argue for three analytical conclusions: First, I want to explain why American social distinctions cannot be understood in terms of the concept of race: the only human race in

\footnotetext{
${ }^{1}$ I owe this thought experiment to a conversation with Samuel R. Delany.
} 
the United States, I shall argue, is the human race. ${ }^{2}$ Second, I want to show that replacing the notion of race with the notion of culture is not helpful: the American social distinctions that are marked using racial vocabulary do not correspond to cultural groups, either. Third, I want to propose that, for analytical purposes, we should use instead the notion of a racial identity, which I will try to explore and explain.

Finally, I will argue for an ethical conclusion: there is a danger in making racial identities too central to our conceptions of ourselves; while there is a place for racial identities in a world shaped by racism, I shall argue, if we are to move beyond racism we shall have, in the end, to move beyond current racial identities.

\subsection{Meaning}

If you'd left Angel Island and traveled much farther east than Ellis Island in the 1920s, sailing across to England, landing at Southampton, and taking the train up to London and on to Cambridge, you could have consulted the leading experts in the Englishspeaking world on questions of meaning. In 1923 Charles K. Ogden and 1. A. Richards had published The Meaning of Meaning: A Study of the Influence of Language upon Thought and of the Science of Symbolism with supplementary essays by various people including the anthropologist Bronislaw Malinowski A year earlier Ludwig Wittgenstein had published the Tractatas LogicoPhilosophicus, which was to become a classic in a field that was not yet called the philosophy of language.

W e do not need to delve deeply into that field. But it will help us later, when we turn to some of the difficult philosophical questions about understanding the idea of race, if we make a distinc-

\footnotetext{
${ }^{2}$ I'm going to avoid my normal custom of using scare-quotes around the word "race" throughout, because in this context it would be question-begging. It would also be confusing since a lot of what I have to say is about the alleged relation between the word "race" and allegedly actual races. So quotes around the word "race" in this piece are for the purpose of distinguishing between use and mention.
} 
tion that was already available when Wittgenstein was writing the Tractatus.

Before I introduce that distinction, however, I want to draw attention to the fact that the issues I am going to be discussing next grow out of a tradition of philosophical reflection that is not directly concerned with ethical matters. It is particularly important, I think, in the context provided by the Tanner lectures, to illustrate how technical philosophy can be of the greatest help in clarifying our moral predicament; and to show that what can be helpful lies as much in the spheres of metaphysics and epistemology and philosophy of language as it does in the field of ethics. Now to the theoretical distinction.

There were in the 1920s - and there are still today - two very different and competing philosophical notions of what it is to give an adequate account of the meaning of a word or expression.

One - we can call this the "ideational" view of meaning which goes back at least to the seventeenth century and the Logic of Port Royal, associates the meaning of a term, like "race," with what the Port Royal Logicians called an "idea." Understanding the idea of race involves grasping how people think about races: what they take to be the central truths about races; under what sorts of circumstances they will apply the idea of race; what consequences for action will flow from that application.

The other picture of meaning — the "referential" view — suggests that to explain what the word "race" means is, in effect, to identify the things to which it applies, the things we refer to when we speak of "races."

These views are not as far apart as they might at first appear. To find out what people are referring to in using the word "race," after all, you might need to know what idea their word "race" expresses: if they had no ideas, no thoughts, about race and if there were no circumstances when they used the word, no consequences to their applying it, then we could hardly suppose that their making 
the sound "race" meant anything at all. In practice, at least, access to an idea of race is probably needed to find the referent.

And, conversely, once we have identified the referent - found, that is, the races - we can assume that people who understand the word "race" have some beliefs that are at least roughly true of races. For if people are talking about races, it is because they have, or think they have, experience of races: and, generally speaking, some of that experience will be reliable. A little bit of knowledge of what races are like combined with a little information about what people are like - how sensory experience works, for example - will allow us to predict at least some of people's ideas about races.

My aim is not to decide between these two broad traditions of conceiving of meaning. Anyone concerned to understand our concept of race ought, I think, to be interested both in the reality of race and in the way people think about it, both in the referential and in the ideational aspects: we can leave it to the philosophers of language to wrangle about which of these ought to have the central place in semantics (or whether, as I suspect, we need both of them).

\subsection{The Ideational Account of Race}

Perhaps the simplest ideational theory of meaning runs like this: what we learn when we learn a word like "race" is a set of rules for applying the term. Everybody who knows what the word "race" means, which means most competent speakers of English, learns the same rules: so that, while people have different beliefs about races, they share some special beliefs - I'll call them the criterial beliefs - that define the concept. These beliefs may not be very high-powered. They might include, for example, the thought that people with very different skin colors are of different races or that your race is determined by the race of your parents. But, on this simplest ideational theory, all of these criterial beliefs have this 
property: someone who doesn't believe these things doesn't understand what the English word "race" means.

The simplest theory would also require that if we collected all these critical beliefs about race and took them all together, they could be thought of as defining the meaning of the word "race." (This is equivalent to saying that there are things that have to be true of something if it is to be a race - conditions necessary for being a race - and that these necessary conditions are, when taken together, sufficient for being a race.) We can use a device invented by the English philosopher Frank Ramsey in the 1920s to make this an explicit definition: Something is a race only in case all the criterial beliefs are true of it. ${ }^{3}$ Let's call this the "strict criterial theory."

The Ramsey definition makes clear the connection between defining a term and questions of existence: there are races if, but only if, there are things that satisfy all the criteria.

For a number of reasons, which again I want to skirt, you won't get many philosophers of language to buy into this strict criterial theory today; there is a general skepticism about it, which goes back, I suppose, to W. V. O. Quine's attack on the idea of the analytic truth, which he called one of the "dogmas of empiricism." For if the strict criterial theory were right, those criterial sentences would be analytically true: they would be sentences that were true simply in virtue of their meanings, and Quine urged us to doubt that there were any of those. ${ }^{4}$

But you don't need high-falutin' semantic arguments to be led to wonder whether we could in fact write a Ramsey-style definition of the word "race." Consider each of the two claims I gave a little while ago. People with very different skin colors are of different races. Your race is determined by the race of your parents.

\footnotetext{
${ }^{3}$ See "Theories" in Frank Ramsey, Foundations: Essays in Philosophy, Logic, Mathematics and Economics, ed. D. H. Mellor (London: Routledge and Kegan Paul, 1978), pp. 101-25.

${ }^{4}$ W. V. O. Quine, "Two Dogmas of Empiricism," in From a Logical Point of View (Cambridge, Mass.: Harvard University Press, 1953), pp. 20-46.
} 
Take the first one. Suppose Jorge were to speak of the Latino "race," and to maintain that the whole range of colors found among people that the U.S. census would classify as Hispanic simply demonstrated that a race didn't have to be fairly monochrome. Is this a mistake about the meaning of the word "race"? Now take the second claim. Two people marry. The wife has one Ghanaian and one British parent. The father's parents are Norwegian. They have children of various shades, one of whom looks, to all intents and purposes, like an average Norwegian. My friend Georg agrees that the mother's parents are of different races and contends that the Norwegian-looking son is Caucasian, but his darker brothers are not. Does Georg not know what "race" means? Apparently, if people with two parents of the same race are of the same race as their parents. For, if your race is determined by the race of your parents, you must have the same race as your full siblings.

It seems to me simply unconvincing to insist that Jorge and Georg don't know what the word "race" means; at least if knowing what it means is knowing whatever you need to know to count as a competent user of the English word "race." This doesn't, of course, prove that we couldn't find a set of beliefs necessary and sufficient for understanding the word "race"; beliefs, that is, that everybody who understands the word "race" must have and such that everybody who has them understands the concept of race. But if even these rather uncontroversial-looking claims turn out to be ones that can be denied by someone who understands the word "race," then one might begin to wonder whether any claims will turn out to be necessary: and if none are necessary, then certainly the conjunction of the necessary conditions won't be sufficient.

Such doubts about the strict criterial theory - in terms of criteria individually necessary and jointly sufficient — lead us on to the next obvious proposal, one that might seem to be suggested by Wittgenstein's use of the notion of a criterion. ${ }^{5}$ Perhaps, what is

${ }^{5}$ See P. F. Strawson, "Wittgenstein's Conception of a Criterion," in Wittgenstein and the Problem of Other Minds, ed. Harold Morick (Brighton, Sussex: Harvester Press, 1981). 
required to know what "race" means is that you should believe most of the criterial beliefs (or a good number of them), but not that you should believe any particular ones. The explicit definition that captures the common notion of those who understand the word "race" will then be given by a modified Ramsey-style definition: A race is something that satisfies a good number of the criterial beliefs. I'll call this the "vague criterial theory."

Accepting this theory has certain important consequences. First of all, it isn't going to allow us to draw a sharp line between not knowing what the word "race" means and having unusual views about races. That boundary is vague, because the expression "a good number" is vague.

Second, the theory admits that among the critical beliefs there are some that are plainly not held by everybody who uses the word "race." These, for example: Most sub-Saharan Africans are of the Negro race. Most Western Europeans are of the white race. Most Chinese are of the yellow race. Everybody has a race. There are only a few races.

There are clearly people who count as understanding the term "race" who don't believe each of these things. Somebody who uses the word "race" may have no thoughts at all about Africa or Western Europe or China - need not know even that they exist. $\mathrm{I}$, as you will see, deny that everybody has $a$ race, because I think nobody has a race: but there are more moderate folks who think that people of so-called mixed-race are neither of the race of their parents nor of some separate race and deny that everybody has a race for that reason. ${ }^{6}$ And there have been physical anthropologists who felt that the only useful notion of race classified people into scores of kinds.

If the strict criterial theory had been true, it would have been easy to argue against the existence of races. One would only have had to find the correct definition and then show that nothing in

\footnotetext{
${ }^{6}$ See Naomi Zack, Race and Mixed Race (Philadelphia: Temple University Press, 1993).
} 
the world actually satisfied it. This looser theory makes it, correspondingly, harder to argue against the existence of races. But the vague criterial theory does suggest a route to understanding the race concept: namely, to explore the sorts of things people believe about what they call "races" and to see what races would have to be like for these things to be true of them. We can then inquire as to whether current science suggests that there is anything in the world at all like that.

Now, suppose there isn't one such thing in the world; then, on this view, there are no races. It will still be important to understand the vague criteria, because these will help us to understand what people who believe in races are thinking. That will be important, even if there are no races: first, because we often want to understand how other people are thinking, for its own sake; and, second, because people act on their beliefs, whether or not they are true. Even if there are no races, we could use a grasp of the vague criteria for the concept race in predicting what their thoughts and their talk about race will lead them to do; ${ }^{7}$ we could use it, too, to predict what thoughts about races various experiences would lead them to have.

Now, I have already declared myself very often on the question whether I think there are any races. I think there aren't. So it is important that I am clear that I also believe that understanding how people think about race remains important for these reasons, even though there aren't any races. To use an analogy I have often used before, we may need to understand talk of "witchcraft" to understand how people respond cognitively and how they act in a culture that has a concept of witchcraft, whether or not we think there are, in fact, any witches.

The ideational view might, therefore, lead you to explore contemporary thought and talk about races. But I think — remember-

${ }^{7}$ Strictly speaking, if there aren't any races, there's no talk or thought about races. So this is a shorthand for "talk they would assent to (or thoughts they would express) using the word 'race' and its cognates." 
ing Jorge and Georg — that this is likely to produce a confusing picture. This is because current ways of talking about race are the residue, the detritus, so to speak, of earlier ways of thinking about race; so that it turns out to be easiest to understand contemporary talk about "race" as the pale reflection of a more full-blooded race-discourse that flourished in the last century. The ideational theory can thus be combined with a historical approach: we can explore the ideational structures of which our present talk is, so to speak, the shadow and then see contemporary uses of the term as drawing from various structures, sometimes in ways that are not exactly coherent.

Before we turn to historical questions, however, let me ask what route to understanding the race-concept is suggested by the referential account of meaning.

\subsection{The Referential Account of Race: Philosophy of Science}

The answer is most easily understood by thinking about an issue in the history and philosophy of science. Looked at from the point of view of current theory some previous theories - earlynineteenth-century chemistry, say - look as though they classified some things - acids and bases, say - by and large correctly, even if a lot of what they said about those things was pretty badly wrong. From the point of view of current theory, you might argue, an acid is, roughly, a proton-donor. ${ }^{8}$ And our recognition of the fact that the classification of acids and bases was in itself an intellectual achievement is recorded in the fact that we are inclined to say that when Sir Humphrey Davy — who, not having any idea of the proton, could hardly be expected to have understood the notion of a proton-donor - used the word "acid," he was nevertheless talking about what we call acids.

The issues here are at the intersection of the philosophy of language and the philosophy of science. And in explaining why it

${ }^{8}$ This is the so-called Bronsted theory of the Danish physical chemist Johannes Nicolaus Bronsted. 
seems proper to think that Sir Humphrey Davy was referring to the things we call proton-donors, even though much of what he believed about acids is not true of proton-donors, philosophers of science have borrowed ideas about reference from recent philosophy of language.

One proposal some have borrowed is what is called the "causal theory of reference." The idea is simple enough: if you want to know what object a word refers to, find the thing in the world that gives the best causal explanation of the central features of uses of that word. If you want to know what the name "New York" refers to, find the object in the world that is at the root of most of the causal chains that lead to remarks containing the expression "New York."

So, in the case of acids, we are urged to believe that the stuffs "out there" in the world that really accounted for the central features of Davy's "acid"-talk really were acids and that this is what accounts for our sense that Davy was not simply talking about something else (or, of course, about nothing at all). Early physiologists (like René Descartes) who talked about "animal spirits" in the nerve fibers, by contrast, we now say were referring to nothing at all: there is no currently recognized stuff that can account for what they said about animal spirits; instead there are truths about sodium pumps and lipid bilayers and synapses. There simply is no substance that was usually present when and only when the expression "animal spirits" was uttered and that behaves at all as they thought animal spirits behaved.

\subsection{The Referential Account of Race: A Proposal}

How can we use these ideas to develop a referential account of the concept of race? Well, we need to explore the sorts of things people have said about what they call "races" and see whether there is something in the world that gives a good causal explanation of their talk. If there is one thing in the world that best explains that talk, then that will be what the word "race" refers to; 
and that can be true, even if it would surprise most people to know that this was what they were really talking about - just as Sir Humphrey Davy would have been surprised to discover that when he said "acids" he was talking about - referring to - proton-donors.

As a practical matter, at least three things are required for us to allow that a past theorist who spoke of $Y_{S}$ and was badly mistaken was nevertheless talking about something, call it $X$ :

1. the existence condition - we must acknowledge the existence of $X$; and

2. the adequacy condition - some of what was thought to be true of what $Y$ denoted must be at least approximately true of $X$; and

3. the uniqueness condition $-X$ must be the best candidate for the job of $Y_{\mathrm{s}}$ referent, so that no other thing that satisfies the existence condition satisfies the adequacy condition equally well.

On the causal theory, what it is for $X$ to be the best candidate for the job of $Y$ s referent in the speech of a community is for $X$ to be the thing that best causally explains their talk about $Y_{\mathrm{s}}$. So what we need to do, on this view, is to explore the history of the way the word "race" has been used and see if we can identify through that history some objective phenomenon that people were responding to when they said what they said about "races."

The difference between ideational and referential theories of meaning, then, is, roughly, that the referential theory requires that we should do a historical version of what the ideational theory permits us to do. On the referential theory, exploring the history of the term is central to understanding what it means. Semantical considerations thus steer us toward historical enquiry.

\subsection{A Note on Method}

The history I am going to explore is the history of the ideas of the intellectual and political elites of the United States and the 
United Kingdom. You might ask why I don't look at the words of more ordinary people: race is statistically most important in ordinary lives. A good question, I say. (This is what you say when you think you have a good answer.) The reason is itself embedded in the history: as we shall see, throughout the nineteenth century the term "race" came increasingly to be regarded, even in ordinary usage, as a scientific term. Like many scientific terms, its being in use among specialists did not stop its being used in everyday life. Treating it as a scientific term meant not that it was only for use by scientists, but that scientists and scholars were thought to be the experts on how the term worked. That is, with the increasing prestige of science, people became used to using words whose exact meanings they did not need to know, because their exact meanings were left to the relevant scientific experts.

In short, there developed a practice of semantic deference: people used words like "electricity" outside the context of natural philosophy or physical science, assuming that the physicists could say more precisely than they could what it meant. This semantic deference thus institutes a new form of what Hilary Putnam has called "linguistic division of labor"; just as older specialties, like theology or law, had for a long time underwritten concepts - the Trinity, landlord - whose precise definition ordinary people didn't know.

The result is that even ordinary users of the term "race," who operated with what I have called vague criteria in applying it, thought of themselves as using a term whose value as a tool for speaking the truth was underwritten by the experts. Ordinary users, when queried about whether their term "race" really referred to anything, would have urged you to go to the experts: the medical doctors and anatomists, and later the anthropologists and philologists and physiologists, all of whom together developed the scientificidea of race.

This makes the term "race" unlike many other terms in our language: "solid," for example. "Solid" is a term that we apply 
using everyday criteria: if I tell you that materials scientists say that a hunk of glass is not a solid but a liquid, you may well feel that they are using the term in a special technical sense, resisting semantic deference. Some people might want to defend the word "race" against scientific attacks on its legitimacy, by denying, in effect, that semantic deference is appropriate here. Of this strategy, I shall make just this observation: if you're going to go that route, you should probably offer some criteria - vague or strict - for applying the term. This is because, as we shall see, the arguments against the use of "race" as a scientific term suggest that most ordinary ways of thinking about races are incoherent.

\subsection{Thomas Jefferson: Abolitionist}

The understandings of "race" I am exploring are American; it seems appropriate enough, then, to begin with a thinker who helped shape the American republic: namely, Thomas Jefferson. And I want to begin with some representative reflections of his from the first quarter of the nineteenth century; for it is in the nineteenth century, I think, that the configuration of ideas about race we have inherited began to take its modern shape.

In Thomas Jefferson's Autobiography - begun, as he says, on January 6,1822 , at the age of 77 -the third president of the United States reproduces his original draft of the Declaration of Independence, with the passages deleted by the Congress "distinguished by a black line drawn under them." There are only two paragraphs entirely underlined in black; and the second, and by far the longer of them, gives, as grounds for complaint against "the present king of Great Britain," ${ }^{10}$ the fact that

[h] e has waged cruel war against human nature itself, violating its most sacred rights of life and liberty in the persons of a distant people who never offended him, captivating \& carrying

${ }^{9}$ Autobiography, in Thomas Jefferson, Writings (New York: Library of America, 1984), p. 18.

${ }^{10}$ Ibid., p. 21. 
them into slavery in another hemisphere, or to incur miserable death in their transportation thither. This piratical warfare, the opprobrium of INFIDEL powers, is the warfare of the CHRISTIAN king of Great Britain. ${ }^{11}$

This first failure at gathering the new republic around the banner of antislavery did not discourage him. Not many pages later, Jefferson reports his equally unsuccessful attempts to persuade the legislature of Virginia to proceed, albeit gradually, toward total emancipation :

But it was found that the public mind would not yet bear the proposition, nor will it bear it even at this day. Yet the day is not distant when it must bear and adopt it, or worse will follow. Nothing is more certainly written in the book of fate than these people are to be free. ${ }^{12}$

So far, I think, we can feel that Thomas Jefferson was not simply ahead of his times, at least in the state of Virginia, but that, allowing for changes in rhetorical taste, he is our moral contemporary.

The sentence that follows disrupts this happy illusion: "Nor is it less certain," the former president writes, "that the two races, equally free, cannot live in the same government." ${ }^{13}$ For Jefferson, who offers here no defense of his view, this is a piece of common sense. Here is a point at which we see one of the central characteristics of Jefferson's way of thinking about race: it is a concept that is invoked to explain cultural and social phenomena, in this case, the alleged political impossibility of a citizenship shared between white and black races.

\subsection{Thomas Jefferson: Race-Theorist}

If we want to know the sources of Jefferson's stern conviction - "Nor is it less certain ..." - we can turn to Query XIV of

\footnotetext{
11 Ibid., p. 22.

12 Ibid., p. 44.

${ }^{13}$ Ibid.
} 
the Notes on the State of Virginia, published four decades earlier, in the 1780s. Emancipation is inevitable, Jefferson has argued; and it is right. But blacks, once emancipated, will have to be sent elsewhere. Jefferson anticipates that we may wonder why, especially given "the expence of supplying, by importation of white settlers, the vacancies they will leave."

Deep rooted prejudices entertained by the whites; ten thousand recollections, by the blacks, of the injuries they have sustained; new provocations; the real distinctions which nature has made; and many other circumstances, will divide us into parties, and produce convulsions which will probably never end but in the extermination of the one or the other race. - To these objections, which are political, may be added others, which are physical and moral. The first difference which strikes us is that of colour. Whether the black of the negro resides in the reticular membrane between the skin and the scarf-skin, or in the scarf-skin itself; whether it proceeds from the colour of the blood, the colour of the bile, or from that of some other secretion, the difference is fixed in nature, and is as real as if its seat and cause were better known to us. And is this difference of no importance? Is it not the foundation of a greater or less share of beauty in the two races? Are not the fine mixtures of red and white, the expressions of every passion by greater or less suffusions of colour in the one, preferable to that eternal monotony, which reigns in the countenances, that immoveable veil of black which covers all the emotions of the other race? Add to these, flowing hair, a more elegant symmetry of form, their own judgment in favour of the whites, declared by their preference for them, as uniformly as is the preference of the Oranootan for the black woman over those of his own species. The circumstance of superior beauty, is thought worthy attention in the propagation of our horses, dogs, and other domestic animals; why not in that of man? $?^{14}$

Apart from this difference of color with its attendant aesthetic consequences, Jefferson observes that there are other relevant dif-

${ }^{14}$ Notes on the State of Virginia (1781-82), in Writings, p. 264. 
ferences: blacks have less hair on their face and bodies; "they secrete less by the kidnies, and more by the glands of the skin, which gives them a very strong and disagreeable odour"; "[t]hey seem to require less sleep. . . They are at least as brave and more adventuresome. But this may perhaps proceed from a want of forethought..." (he has forgotten the Aristotelian proposal that bravery is intelligent action in the face of danger). "They are more ardent after their female; but love seems with them to be more an eager desire, than a tender delicate mixture of sentiment and sensation. Their griefs are transient." Is

Comparing them by their faculties of memory, reason, and imagination, it appears to me, that in memory they are equal to the whites; in reason much inferior, as I think one could scarcely be found capable of tracing and comprehending the investigations of Euclid; and that in imagination they are dull, tasteless, and anomalous.... [Among African-Americans] (slome have been liberally educated, and all have lived in countries where the arts and sciences are cultivated to a considerable degnee, and have had before their eyes samples of the best works from abroad. The Indians, with no advantages of this kind, will often carve figures on their pipes not destitute of design and merit. ... They astonish you with strokes of the most sublime oratory; such as prove their reason and sentiment strong, their imagination glowing and elevated. But never yet could I find that a black had uttered a thought above the level of plain narration; never see even an elementary trait of painting or sculpture. In music they are more generally gifted than the whites with accurate ears for tune and time, and they have been found capable of imagining a small catch. . . . Misery is often the parent of the most affecting touches in poetry. Among the blacks is misery enough, God knows, but no poetry. . . . Religion indeed produced a Phyllis Whately [sic]; but it could not produce a poet. The compositions published under her name are below the dignity of criticism. ${ }^{16}$

\footnotetext{
${ }^{15}$ Ibid., p. 265.

${ }^{16}$ Ibid., p. 206.
} 
Jefferson has nicer things to say about Ignatius Sancho, an African whose letters had been published in London in 1782. ${ }^{17}$ And the judiciousness of his tone here adds, of course, greatly to the weight of his negative judgments. A little later in the same long paragraph - it is nearly six pages in the Library of America edition -he writes:

Whether further observation will or will not verify the conjecture, that nature has been less bountiful to them in the endowments of the head, I believe that in those of the heart she will be found to have done them justice. That disposition to theft with which they have been branded, must be ascribed to their situation, and not to any depravity of the moral sense. ${ }^{18}$

Though he tells us that "[t]he opinion, that they are inferior in the faculties of reason and imagination, must be hazarded with diffidence, ${ }^{\prime 19}$ he nevertheless concludes:

I advance it as a suspicion only, that the blacks whether originally a distinct race, or made distinct by time and circumstances, are inferior to the whites in the endowments both of body and mind. It is not against experience to suppose, that different species of the same genus, or varieties of the same species, may possess different qualifications. Will not a lover of natural history then, one who views gradations in all the races of animals with the eye of philosophy, excuse an effort to keep those in the department of man as distinct as nature has formed them. This unfortunate difference of colour, and perhaps of faculty, is a powerful obstacle to the emancipation of these people. ${ }^{20}$

After so conspicuously fair and balanced a discussion, it would have been hard not to share Jefferson's "suspicion." His very cau-

${ }^{17}$ Ignatius Sancho (1729-so), Letters of the Late lgnatius Sancho, an African (London: Printed by J. Nicols, 1782).

${ }^{18}$ Jefferson, Notes, pp. 268-69.

${ }^{19}$ Ibid., p. 269.

${ }^{20}$ Ibid., p. 270. 
tion here adds to rather than detracts from the force of his conclusions; and after so much attention to the "difference ... of faculty," it is easy to miss the fact that Jefferson believes that Negroes and whites must be kept apart, even if his "suspicion" is mistaken. For Jefferson the political significance of race begins and ends with color.

Jefferson's claims here about the Negro's faculties went neither unnoticed nor unanswered. And we can find, in his letters as in the Notes, evidence that he remained willing to entertain the possibility that his skepticism about the capacities of the Negro was unwarranted. In a letter of August 30, 1791, to Benjamin Banneker, who had worked on the design of the Capitol in Washingtonthis was certainly one Negro gentleman who was capable of "comprehending the investigations of Euclid" - Jefferson wrote:

No body wishes more than I do to see such proofs as you exhibit, that nature has given to our black brethren, talents equal to those of the other colors of men, and that the appearance of want in them is owing merely to the degraded condition of their existence, both in Africa \& America. ${ }^{21}$

And he repeats the sentiment in a letter to Henri Grégoire. Thanking the Abbé for sending him a copy of his La littérature des nègres (1808), Jefferson writes:

Be assured that no person living wishes more sincerely than I do, to see a complete refutation of the doubts I have myself entertained and expressed on the grade of understanding allotted to them by nature, and to find that in that respect they are on a par with ourselves. My doubts were the results of personal observation [one wonders, a little, about the Orangutan here) on the limited sphere of my own State, where the opportunities for the development of their genius were not favorable, and those of exercising it still less so. I expressed them therefore with great hesitation; but whatever be their degree of talent it is no measure of their rights. Because Sir Isaac

${ }^{21}$ August 30, 1791, to Benjamin Banneker, Letters, in Writings, p. 982. 
Newton was superior to others in understanding, he was not therefore lord of the person or property of others. ${ }^{22}$

\subsection{The Enlightenment Idea}

I have quoted so much of Jefferson in part, of course, because Jefferson is an important figure in the history of American debates about racial politics; but mostly because in these passages I have cited we see something entirely representative of the best thinking of his day: the running together of biology and politics, science and morals, fact and value, ethics and aesthetics. Jefferson is an intelligent, sensitive, educated American shaped by the Western intellectual currents we call the Enlightenment: if we query these conflations, we are querying not so much an individual as the thinking of a whole culture.

Let us explore the structure of Jefferson's explanation of why black and white races cannot live together in equality and harmony. He begins with suggestions that do not especially rely on the character of the race concept: prejudice, on the part of whites, and justified resentment, on the part of blacks. But almost immediately he moves on to speak of "the real distinctions which nature has made." And the first of these "physical and moral" differences is the primary criterion for dividing the black from the white race: skin color. Notice that in a passage devoted to a sociopolitical question - let me repeat that the issue here is why the races can't live together in harmony - he spends a great deal of time on theories about skin color and its consequences for the physiology of the expression of the emotions. Notice, too, however, that Jefferson holds the dark skin color and the nature of Negro hair to be relevant in part because they mean that whites are of "superior beauty" to blacks; an argument that appears to presuppose that beauty is a condition for fraternity; or even - something that the passage hints at rather than asserting — that men can share citizen-

\footnotetext{
${ }^{22}$ February 25, 1806, to Henri Grégoire, Letters, in Writings, p. 1202.
} 
ship with other men only if they find each other's women sexually attractive. I think we can assume that if Jefferson had seen that either of these premises was implicit in his argument, he might well have rejected (especially the second of) them: my point is only that it requires some such assumption to make his observations genuinely relevant to the question at hand.

Jefferson continues to talk about physical matters and their aesthetic consequences - hairlessness, kidneys, sweat — before moving on to discuss questions of the moral character of the Negro - bravery, lustfulness, crudeness of feeling (no "tender, delicate mixture of sentiment and sensation"), shallowness (those transient griefs) - and ends, at last, with the intellectual capacities — or rather, incapacities — of black people.

This passage is representative of late-eighteenth-century discussions of race because, as I say, it brings together considerations that we are likely to think should be kept distinct. Remember always why the intellectual incapacity of blacks — their inferior reason -is invoked: not to justify unequal treatment - Jefferson, the democrat, clearly believes that intellectual superiority does not warrant greater political power, superior rights - but as part of a catalogue of differences, which, taken together, make it certain that blacks and whites cannot live together as fellow-citizens.

And it is clear that Jefferson believes that the answer to this question lies in what we would call differences in physiology, and moral and cognitive psychology, distinctions which, if they are real, we too are likely to regard as "distinctions which nature has made."

Not only, then, is race, for Jefferson, a concept that is invoked to explain cultural and social phenomena, it is also grounded in the physical and the psychological natures of the different races; it is, in other words, what we would call a biological concept.

\subsection{From Natural History to Race Science}

I say that it was what we would call a biological concept, because the science of biology did not exist when Jefferson was writ- 
ing the Notes. ${ }^{23}$ What did exist was natural history; and Jefferson would have agreed that race was a natural historical notion, as much as was the idea of species that Linnaeus had developed and that Buffon had popularized. ${ }^{24}$ To think of race as a biological concept is to pull out of the natural history of humans a focus on the body -its structure and function - and to separate it both from mental life - the province of psychology — and from the broader world of behavior and of social and moral life. If Jefferson's discussion, with its movement from questions of the morphology of the skin, to discussions of sexual desire, to music and poetry, strikes us as a hodge-podge, it is because we live on the other side of a great intellectual chasm, which opens up with increasing speed through the nineteenth century. For we live now with a new configuration of the sciences; and, more especially, with the differentiation from the broad field of natural history of anatomy, physiology, psychology, philology (i.e., historical linguistics), sociology, anthropology, and a whole host of even more specialized fields that gradually divided between them the task of describing and understanding human nature.

Jefferson's discussion is representative of a transition in the way the word "race" is used in reflecting on the characters of different kinds of peoples: the outer manifestations of race- the black skin of the Negro, the white skin and round eyes of the European, the oval eyes of the Oriental — have taken their place for him beside other, less physical, criteria, in defining race. The race of a person is expressed in all these ways, physical, moral, intellectual: they are referred back, so to speak, to a common cause or ground.

23 "The term 'biology' first appeared in a footnote in an obscure German medical publication of 1800 . Two years later it again appeared, apparently independently, and was given ample publicity in treatises by a German naturalist (Gottfried Treviranus) and a French botanist turned zoologist (Jean-Baptiste de Lamarck)" (William Coleman, Biology in the Nineteenth Century: Problems of Form, Function and Transformation, Cambridge History of Science Series [Cambridge: Cambridge University Press, 1971], p. 1).

${ }^{24}$ Carolus Linnaeus, Systema Naturae, in which people are classified as Homo sapiens, appeared in 1735 . 


\subsection{Before Natural History}

If we look back, for a moment, to the seventeenth-century traditions of English thought that are Jefferson's background, we see a different configuration of ideas, in which the physical body was important not as a cause but as a sign of difference. ${ }^{25}$ Remember Othello. As G. K. Hunter has well expressed the matter:

Shakespeare has presented to us a traditional view of what Moors are like, i.e. gross, disgusting, inferior, carrying the symbol of their damnation on their skin; and has caught our over-easy assent to such assumptions in the grip of a guilt which associates us and our assent with the white man representative of such views in the play - Iago. Othello acquires the glamour of an innocent man that we have wronged, and an admiration stronger than he could have achieved by virtue plainly represented. ... ${ }^{26}$

This device works only if the audience accepts that the Moor is not, simply by virtue of his Moorish physical inheritance, incorrigibly evil. Othello's blackness is a sign of his Moorishness; and it can associate him, through that sign, with the infidel (since, unlike the Moor of Venice, most Moors are not Christian) and thus with moral or religious evil.

A similar point applies to the treatment of "the Jew" in both Shakespeare's Merchant of Venice and Christopher Marlowe's Jew of Malta. When Shylock, in what is surely his best-known speech, asks "Hath not a Jew eyes?" he is insisting that his body is a human body: and thus essentially the same as the body of a Gentile. $\mathrm{He}$ claims a status that depends on accepting that whatever is dis-

${ }^{25}$ For more on the background here, see Hugh B. MacDougall, Racial Myth in English History: Trojans, Teutons, and Anglo-Saxons (Montreal, Canada: Harvest House; Hanover, N.H., and London, England: University Press of New England, 1982); Reginald Horsman, Race and Manifest Destiny: The Origins of American Racial Anglo-Saxonism (Cambridge, Mass.: Harvard University Press, 1981).

${ }^{26}$ George K. Hunter, "Othello and Race-Prejudice," in Dramatic Identities and Cultural Tradition: Studies in Shakespeare and his Contemporaries (Liverpool: Liverpool University Press, 1978), pp. 45-46. 
tinctive about him it is not his physical descent - what we would call his biological inheritance. So too, when Barabas in Marlowe's play is faced, by the Governor of Malta, with the accusation that Christ's blood "is upon the Jews," he replies:

But say the Tribe that I descended of Were all in general cast away for sin, Shall I be tried by their transgression? ${ }^{27}$

Barabas here makes the essentially Christian point that sin and righteousness are individual matters; that they are precisely not inherited from "the Tribe that I descended of." If Barabas deserves punishment, it must be for something he has done: and, in fact, the Governor's reply demonstrates a grasp of this point. For he asserts that the issue is not Barabas's descent but his Jewish faith: the issue, therefore, cannot be conceptualized as simply racial. This is (a religious) anti-Judaism not (a racial) anti-Semitism (which is, of course, not much consolation for Barabas).

There is good reason, then, to interpret these Elizabethan stereotypes, which we might naturally think of as rooted in notions of inherited dispositions (that is, of biology), as having much more to do with the idea of the Moor and the Jew as infidels; unbelievers whose physical differences are signs (but not causes or effects) of their unbelief.

But while Jefferson has thus moved toward conceiving of racial difference as both physical and moral, he is not yet committed to the view that race explains all the rest of the moral and social and political matter that is drawn into the portrait of the Negro in the Notes. The letters to Banneker and Grégoire reveal a man who leaves open - at least in theory — the possibility "that nature has given to our black brethren, talents equal to those of the other colors of men"; and throughout the Notes Jefferson writes with real affection and respect about Indians, who "astonish you with 42.

${ }^{27}$ Christopher Marlowe, The Jew of Malta (London: Methuen, 1987), 11.340- 
strokes of the most sublime oratory; such as prove their reason and sentiment strong, their imagination glowing and elevated." The differences between whites and Indians, for Jefferson, hardly constitute a difference of essential natures.

If we move on another fifty or so years from Jefferson's Autobiography, we enter once more a new intellectual landscape: one in which there is no longer any doubt as to the connection between race and what Jefferson calls "talent": and here, of course, the word "talent" - deriving from the New Testament parable of the talents - refers to inherited — to "native" — capacities.

\subsection{Matthew Arnold: On the Study of Celtic Literature}

Let me turn, then, from Jefferson, and move on into the second half of the nineteenth century, to the work of a poet and critic who, like Jefferson, uses the concept of race to explain the moral and the literary, but unlike him, is convinced that biological inheritance helps determine every aspect of racial capacity: Matthew Arnold.

Arnold was the greatest English critic of the nineteenth century. He was also a central Victorian poet, an influential essayist, and lecturer: in short, a very public intellectual, whose influence was extended into the United States, not least by his lecture tour here in 1883 to 1884 (in his early sixties) which led to the publication, in 1885, of Discourses in America.

In 1857 Matthew Arnold was elected to the professorship of poetry at Oxford, a position he held for about a decade. Ten years later, he published a series of lectures he had given as professor of poetry, On the Study of Celtic Literature. Arnold begins with a somewhat melancholy description of a visit to an Eisteddfod a festival of Welsh bards -in Llandudno in North Wales. On an "unfortunate" day - "storms of wind, clouds of dust, an angry, dirty sea" ${ }^{28}$ - Arnold sits with a meager crowd listening to the

\footnotetext{
${ }^{28}$ Matthew Arnold, On the Study of Celtic Literature and on Translating Homer (New York, Macmillan and Co., 1883), p. 6.
} 
last representatives of a great poetic tradition performing for a small audience in a language he admits he does not understand. ("I believe it is admitted," Arnold observes drily, "even by admirers of Eisteddfods in general, that this particular Eisteddfod was not a success." $)^{29}$

This sad episode is only the preliminary, however, to an argument for the view that the ancient literature of the Celts - of Ireland and Wales, in particular - is part of the literary heritage of Britain; even of those Britons in England who by then conceived of themselves as heirs to a Saxon heritage and were inclined, by and large, to hold the Irish Celts, especially, in less than high regard.

Here is how Arnold makes his case:

. . . here in our country, in historic times, long after the Celtic embryo had crystallised into the Celt proper, long after the Germanic embryo had crystallised into the German proper, there was an important contact between the two peoples; the Saxons invaded the Britons and settled themselves in the Britons' country. Well, then, here was a contact which one might expect would leave its traces; if the Saxons got the upper hand, as we all know they did, and made our country be England and us be English, there must yet, one would think, be some trace of the Saxon having met the Briton; there must be some Celtic vein or other running through us.

... though, as I have said, even as a matter of science, the Celt has a claim to be known, and we have an interest in knowing him, yet this interest is wonderfully enhanced if we find him to have actually a part in us. The question is to be tried by external and internal evidence; the language and physical type of our race afford certain data for trying it, and other data are afforded by our literature, genius, and spiritual production generally. Data of this second kind belong to the province of the literary critic; data of this first kind to the province of the philologist and the physiologist.

The province of the philologist and the physiologist is not mine; but this whole question as to the mixture of Celt with

${ }^{29}$ Ibid., p. 8 . 
Saxon in us has been so little explored, people have been so prone to settle it off-hand according to their prepossessions, that even on the philological and physiological side of it I must say a few words in passing. ${ }^{30}$

The ensuing discussion of what Arnold calls "physiology" is not what we should expect: it turns out that he is simply going to discuss the likelihood of mixture (i.e., breeding) between the races. He cites, for example, the opinion of a certain Monsieur Edwards that "an Englishman who now thinks himself sprung from the Saxons or the Normans, is often in reality the descendant of the Britons." ${ }^{31}$ The appeal to philology, however, might seem to suggest an alternative mechanism for the transmission of racial traits - namely, through language; but, in fact, philology is, for Arnold and his contemporaries, largely a guide to racial filiation, with those whose languages are most closely related being also most closely related by blood. Arnold is clear that language can, in fact, be misleading:

How little the triumph of the conqueror's laws, manners, and language, proves the extinction of the old race, we may see by looking at France; Gaul was Latinised in language manners, and laws, and yet her people remained essentially Celtic. ${ }^{32}$

But he is also convinced, as I say, that it can be a guide to racial character.

\subsection{Racialism}

What Arnold lays out in these passages is the essence of what I call racialism. He believed - and in this he was typical of edu-

${ }^{30}$ Ibid., pp. 66-67.

${ }^{31}$ Ibid., p. 72. Arnold never explicitly discusses sex, of course; and so we are left with the possibility of interpreting this as meaning that there are English people who are of wholly British (i.e., Celtic) descent or thinking that there are some of partially British (i.e., Celtic) descent. Given, however, that some of the former have "passed" many centuries ago, the existence of the latter can be assumed.

${ }^{32}$ Ibid., p. 69. 
cated people in the English-speaking world of his day - that we could divide human beings into a small number of groups, called "races," in such a way that the members of these groups shared certain fundamental, heritable, physical, moral, intellectual, and cultural characteristics with each other that they did not share with members of any other race.

There are a few complications to this basic picture, which we should bear in mind. First, there are two major ways in which counterexamples to claims about the members of the race could simply be ruled out. It was acknowledged that there were, to begin with, in all races, as there are in animal species, occasional defective members: in animals, the two-headed pigs and three-legged cats so beloved of tabloid journalism in my homeland of Ghana; in human beings, the mute, the mentally disabled, the blind. These individuals were not to count against the general laws governing the racial type. Similarly, the norm for each race might be different for males and females, so that a racial type might be defined by two norms, rather than one.

A second complication derives from the fact that many of the characteristics of the various races were described as dispositions or tendencies: a single person who was not defective might still differ from the average member of his race because his individual character dominated the natural tendencies he had inherited in his racial essence. Celts might all tend toward the sentimental: but a particular Welshman might, through an exercise of will, conquer his natural racial temper. As a result the failure of an individual to fit the norm for her race would not by itself refute the theory, for it might be that that person had simply conquered her inherited disposition. Many of what I shall call the characteristics of a race were thus not, to use a modern term, phenotypic: they did not necessarily display themselves in the observable behavior of every individual. ${ }^{33}$

${ }^{33}$ Nevertheless, it is a point about the logic of dispositional terms that it is hard (though not impossible) to make sense of applying them to the members of a 
These characteristics, then, that each normal woman (and man) of a race was supposed to share with every other woman (and man) together determined what we can call the essence of that race; they were characteristics that were necessary and sufficient, taken together, for someone to be a normal member of the race. Arnold's concept of race should, then, provide the materials for what I have called a strict criterial theory of the meaning of the term "race."

Arnold was uncharacteristic of his age in many ways, and one of them is the cosmopolitanism - or, at least, the Europeanism of his temperament: he quotes frequently from French and German scholars. And on the question of race his views conformed with what was coming to be the common sense of Western European intellectuals.

Arnold's discussion in On the Study of Celtic Literature makes it plain that he believes that the racial essence accounts for more than the obvious visible characteristics of individuals and of groups - skin color, hair, shape of face — on the basis of which we decide whether people are, say, Asian- or Afro-Americans. For a racialist, then, to say people are "Negro" is not just to say that they have inherited a black skin or curly hair: it is to say that their skin color goes along with other important inherited characteristics - including moral and literary endowments. By the end of the nineteenth century most Western scientists (indeed, most educated Westerners) believed that racialism was correct and theorists sought to explain many characteristics — including, as we see here, the character of literatures - by supposing that they were inherited along with (or were in fact part of) a person's racial essence.

\subsection{Mixing Essences}

In the British people, Arnold is arguing, not only are there some whose ancestors are Celt - the first Britons - and some

group if no one in the group ever displays the disposition: see Anthony Appiah, Assertion and Conditionals (Cambridge and New York: Cambridge University Press, 1985), chapter 2 , section 4. 
whose ancestors are Saxon, but these two lines have become literally joined through intermarriage, and the character of British literature is thus not only the product of a cultural syncretism, but a joining of the essences of two races. Thus, while the Celtic essence survives, it survives mixed with a Saxon essence: the character of the English thus contains both essences; both are available as driving energies of English poetry.

All tendencies of human nature are in themselves vital and profitable; when they are blamed, they are to be blamed relatively, not absolutely. This holds true of the Saxon's phlegm as well as the Celt's sentiment. Out of the steady humdrum habit of the creeping Saxon, as the Celt calls him, - out of his way of going near the ground - has come, no doubt, Philistinism, that plane of essentially Germanic growth, flourishing with its genuine marks only in the German fatherland, Great Britain and her colonies, and the United States of America; but what a soul of goodness there is in Philistinism itself! and this soul of goodness I, who am often supposed to be Philistinism's moral enemy merely because I do not wish it to have things all its own way, cherish as much as anybody. This steady-going habit leads at last ... up to science, up to the comprehension and interpretation of the world. ${ }^{34}$

Arnold has to account as well for the presence of Norman blood in this brew of racial essences, and once this is done he has all the elements he needs for constructing a picture of the British racial hybrid.

I have got a rough, but, I hope, clear notion of these three forces, the Germanic genius, the Celtic genius, the Norman genius. The Germanic genius has steadiness as its main basis, with commonness and humdrum for its defect, fidelity to nature for its excellence. The Celtic genius, sentiment as its main basis, with love of beauty, charm, and spirituality for its excellence, ineffectualness and self-will for its defect. The Norman genius, talent for affairs as its main basis, with strenuousness

\footnotetext{
${ }^{34}$ Arnold, Celtic Literature, pp. 83-84.
} 
and clear rapidity for its excellence, hardness and insolence for its defect. And now to try and trace these in the composite English genius. ${ }^{35}$

Part of the evidence that Arnold offers that the character of England is the product of the intermixing of these racial types is in the contrast between English prose - exemplified in the news pages of the London Times - and German - exemplified in the Cologne Gazette. "At noon a long line of carriages extended from Pall Mall to the Peer's entrance of the Palace of Westminster," writes the correspondent of the Times (we must turn to the editorial pages to discover why it was known as "the Thunderer"). While the Gazette has "Nachdem die Vorbereitungen zu dem auf dena Gürzenich-Saale zu Ehren der Abgeordneten Statt finden sollenden Bankette bereits vollständig getroffen worden waren, fand heute vormittag auf polizeiliche Anordnung die Schliessung sämmtlicher Zugänge zum Gürzenich Statt" ${ }^{36}$ Arnold concludes:

Surely the mental habit of people who express their thoughts in so very different a manner, the one rapid, the other slow, the one plain, the other embarrassed, the one trailing, the other striding, cannot be essentially the same. ${ }^{37}$

It follows that there must be something other than the common Teutonic racial stock, which Germans and Saxons share, that accounts for the difference: this is evidence, then, on the racialist view, for the proposition that the British stock has been hybridized with some other race.

Arnold makes the same sort of appeal to race - this time at a greater level of generality, discussing the contrast between IndoEuropean and Semitic races - in Culture and Anarchy, a work that is much more widely known. In these essays, based on articles

\footnotetext{
${ }^{35}$ Ibid., p. 87.

${ }^{36}$ Ibid., p. 88.

${ }^{37}$ Ibid., pp. 88-89.
} 
that first appeared in Cornhill Magazine in 1867 and 1868, and then in book form in 1869, Arnold wrote:

Science has now made visible to everybody the great and pregnant elements of difference which lie in race, and in how signal a manner they make the genius and history of an IndoEuropean people vary from those of a Semitic people. Hellenism is of Indo-European growth, Hebraism of Semitic growth; and we English, a nation of Indo-European stock, seem to belong naturally to the movement of Hellenism. But nothing more strongly marks the essential unity of man than the affinities we can perceive, in this point or that, between members of one family of peoples and members of another; and no affinity of this kind is more strongly marked than that likeness in the strength and prominence of the moral fibre, which, notwithstanding immense elements of difference, knits in some special sort the genius and history of us English, and of our American descendants across the Atlantic, to the genius and history of the Hebrew people. Puritanism, which has been so great a power in the English nation, and in the strongest part of the English nation, was originally the reaction, in the sevententh century, of the conscience and moral sense of our race, against the moral indifference and lax rule of conduct which in the sixteenth century came in with the Renascence. It was a reaction of Hebraism against Hellenism. . . ${ }^{38}$

Arnold makes a move here that is similar to the one he makes in the discussion of Celts and Saxons: he invokes race - which in Jefferson is invoked to account for division - in a context where he is arguing toward universality. Hebraism is Arnold's name for the tendencies in Western culture that are owed to its JudaeoChristian religious heritage: he is convinced of the importance of Christianity and insists, in Culture and Anarchy, on the necessity of maintaining an established - that is, a state-supported - church in England. He is not, then, an enemy of Hebraism as such: every

${ }^{38}$ Matthew Arnold, Culture and Anarchy, ed. Samuel Lipman (New Haven: Yale University Press, 1994), p. 95. 
race, he insists here as much as in On the Study of Celtic Literature, has emblematic excellences as well as distinctive defects. The ideal for Britain, Arnold argues, is to construct a judicious mixture of Hebraism and Hellenism: the British, lacking Semitic blood, are not, by nature, Hebraists. The point, then, is that by Arnold's day even someone wanting to point to what was shared between two human groups was likely to do so in terms of the notion of race, a notion that was largely defined in terms of what separates people. ${ }^{39}$

These passages from the two sources, taken together, reveal a great deal of the structure of racialist thinking. Arnold displays both the flexibility of the view and some of its characteristic obscurities. Part of the flexibility flows from the fact that racial classification proceeds, as we see, at different levels: the Saxons and the Celts are both Indo-European. Differences between them are differences within the broader Indo-European race. When we need similarities, we can appeal to the higher level — the subsuming category of the Indo-European; when we need differences, we can move lower down the taxonomic tree. In the United States, the differences between the Irish and the Anglo-Saxons could be used to account for the cultural and moral deficiencies - real or imaginary —of Irish immigrants; but their whiteness could be used to distinguish them from the Negro.

But there is also something of a muddle here: if the Celtic and the Saxon essences are so opposite, what is an individual like who inherits both of them? What would a man be like who was steady and sentimental; suffered from commonness and humdrummery and ineffectualness and self-will; was faithful to nature and loved "beauty, charm, and spirituality" ? What is lacking in Arnold's work is any theory of inheritance, any mechanism for explaining

${ }^{39}$ Arnold's fairly benign mobilization of the idea of a Celtic race here contrasts favorably with contemporary and later uses of it in discussions of the Irish character both in England and in the United States. In late-nineteenth-century America, the place of the Irish "race" within the broader European races was distinctly below that of the so-called Anglo-Saxon and Nordic races and, in some contexts, closer to that of the Negro. 
how the character of a race survives through the generations, transmitted in the bodies of its members, and any account of the laws that govern the interactions of racial essences. Without these racialism makes no particular predictions about racial hybrids: a fact that is of the greatest importance since, if we are considering races at the taxonomic level of Celt and Saxon, there were very few peoples known to Arnold and his contemporaries who could plausibly have been thought to be unmixed.

What is also lacking is an answer to the question how we balance the effects of race and the effects of environment. Culture and Anarchy is in large measure about why the British are not Hellenic enough. If the British inherit naturally the tendencies of Hellenism with their Indo-European blood and language, why is British culture not too suffused with Hellenism (as the theory should predict) but too dominated by Hebraism?

The answer Arnold gives has to do with the role of Christianity in spreading Hebraism, not by racial admixture but by cultural influence. And if the spread of Hebraism is a cultural phenomenon, then the Hellenism carried in the British blood, the racial essence, cannot be determinative of how a people will act. In Culture and Anarchy he says :

And if, - whereas the Semitic genius placed its highest spiritual life in the religious sentiment, and made that the basis of its poetry, - the Indo-European genius places its highest spiritual life in the imaginative reason, and makes that the basis of its poetry, we are none the better for trying to make ourselves Semitic, when nature has made us Indo-European, and to shift the basis of our poetry. We may mean well; all manner of good may happen to us on the road we go; but we are not on our real right road, the road we must in the end follow." 40

If this determinism of race is correct, isn't the Hebraism of England, described in Culture and Anarchy, evidence that the English 
are in fact not Indo-European but Semitic ? And what significance for the issue of environment versus racial essence should we give to the claim, in a letter of June 21,1865 , that "a nation is really civilised by acquiring the qualities it by nature is wanting in"? 41

There is no doubt that these questions could have been answered: the idea, to which I referred earlier, that members of races inherited tendencies rather than more strictly phenotypic or behavioral properties could be invoked, for example, in an account of the interaction of racial character, individual traits, and environment. Indeed, in a period before Mendelism, it was possible to believe, with Lamarck, that the environment acted on individuals to produce in them changes that they transmitted to their children not through teaching but through bodily inheritance.. After Mende1 and Darwin, one can maintain that the environment acts on bodily heredity only slowly and over many generations; ${ }^{42}$ but until then the distinction between cultural innovation, on the one hand, which allows a group to develop and transmit a new behavioral response extremely quickly, and biological change, on the other, which moves with a stately and glacial torpor, was unavailable. In Arnold's day, one could have argued that the Hebraism of England was both racially inherited and recently acquired: acquired, for example, in the first age of Puritanism.

Without answers to questions such as these, however, what is masquerading as an empirical, even a scientific, theory is remarkably insensitive to evidence. These deficiencies in Arnold are found in other race thinkers of the period-and, as we shall see, they are by no means limited to those who address the less physical that is the moral or cultural - traits of races.

41 Joseph Carroll, The Cultu ral Theory Of Matthew Arnold (Berkeley: University of California Press, 1982).

42 Perhaps one should also add August Meismann's doctrine of the separation of the somatoplasm and the germplasm as a crucial further bolster, from cytology, to this argument. See Garland Allen, Life Science in the Twentieth Century, Cambridge History of Science Series (Cambridge: Cambridge University Press, 1978). 


\subsection{The Origins of Literary Racialism}

Arnold's identification of literature as a key to the national spirit is in a tradition we can trace back a century earlier to Johann Gottfried Herder.

In his On the New German Literature: Fragments of 1767, Herder - who is, in some ways, the first important philosopher of modern nationalism - put forward the notion that language, far from being (as the received Aristotelian tradition had it) the merely material cause of a work of literature (i.e., just what it happened to be written in) is not just "a tool of the arts and sciences" but "a part of them." "[W]hoever writes about the literature of a country," Herder continued, "must not neglect its language." Herder's notion of the Sprachgeist - literally the "spirit" of the language - embodies the thought that language is more than the medium through which speakers communicate.

Herder's ideas became part of mid-nineteenth-century common sense. The consensus was well expressed by Thomas Carlyle, the British essayist and man-of-letters, in 1831 - less than a decade after Jefferson's Autobiography -in a discussion, in the Edinburgh Review, of a history of German poetry:

[T] he history of a nation's Poetry is the essence of its History, political, scientific, religious. With all these the complete Historian of a national poetry will be familiar; the national physiognomy, in its finest traits, and through its successive stages of growth will be clear to him; he will discern the grand spiritual Tendency of each period. ....

That the "nation" here is not a political unit but a group defined by descent is evident from the fact that there was, in 1831,no single German state: Bismarck's time had not yet come. Between Carlyle's essay and Arnold's lectures, talk of "nations" was displaced by talk of "race."

${ }^{43}$ Thomas Carlyle, Critical and Miscellaneous Essays: Collected and Republished, vol. 3 (London: Chapman and Hall, 1869), p. 225. 
Herder himself had had to make a sharp distinction between nations and states because in eighteenth-century Europe there was not even an approximate correlation between linguistic and political boundaries. ${ }^{44}$ The modern European nationalism, which produced, for example, the German and Italian states, involved trying to create states to correspond to nationalities: nationalities conceived of as sharing a civilization, and, more particularly, a language and literature. Exactly because political geography did not correspond to Herder's nationalities, he was obliged to draw a distinction between the nation as a natural entity and the state as the product of culture, as a human artifice.

But with the growing influence of the natural sciences - the separation out of specialties for natural history and the professionalization of scientific research - what is natural in human beings - the human nature whose story natural history told came increasingly to be the subject of such sciences as biology and anthropology. Inevitably, then, the nation comes more and more to be identified not just by common descent but also as a biological unit, defined by the shared essence that flows from that common descent.

Imposing the Herderian identification of the core of the nation with its national literature on top of the racial conception of the nation, we arrive at the racial understanding of literature that Arnold expresses: a way of thinking that flourishes from the midnineteenth century in the work of the first modern literary historians. Hippolyte Taine's monumental History of English Literature, published in France in the 1860s — perhaps the first modern literary history of English - begins with the words: "History has been transformed, within a hundred years in Germany, within sixty in France, and that by the study of their literatures." 45

\footnotetext{
${ }^{44}$ It is important to remember that the correlation remains in most parts of the world quite rough and ready.

${ }^{45}$ Hippolyte A. Taine, History of English Literature, trans. H. Van Laun (London: Chatto and Windus, 1897), p. 1.
} 
But he is soon telling us that

a race, like the Old Aryans, scattered from the Ganges as far as the Hebrides, settled in every clime, and every stage of civilization, transformed by thirty centuries of revolutions, nevertheless manifests in its languages, religions, literatures, philosophies, the community of blood and of intellect which to this day binds its offshoots together. ${ }^{46}$

What is revealed, in short, by the study of literature that has transformed the discipline of history is the "moral state" of the race whose literature it is. It is because of this conception that Taine finds it proper to start his study of English literature with a chapter on the Saxons; so that chapter 1, book 1, of Taine's History begins not in England at all, but in Holland:

As you coast the North Sea from Scheldt to Jutland, you will mark in the first place that the characteristic feature is the want of slope: marsh, waster, shoal; the rivers hardly drag themselves along, swollen and sluggish, with long, black-looking waves. ...

The "Saxons, Angles, Jutes, Frisians ... [and] Danes" who occupied this region of Holland at the beginning of the first millennium are, according to Taine, the ancestors of the English $;^{48}$ but since they themselves are of German descent, he also refers, in describing this "race" a few pages later, to some of their traits reported in Tacitus.

It is the conception of the binding core of the English nation as the Anglo-Saxon race that accounts for Taine's decision to identify the origins of English literature not in its antecedents in the Greek and Roman classics that provided the models and themes of so much of the best-known works of English "poesy"; not in the

\footnotetext{
${ }^{46}$ Ibid., p. 17.

47 Ibid., p. 37.

${ }^{48}$ Ibid., p. 39.
} 
Italian models that influenced the drama of Marlowe and Shakespeare; but in Beowulf, a poem in the Anglo-Saxon tongue, a poem that was unknown to Chaucer and Spenser and Shakespeare, the first poets to write in a version of the English language that we can still almost understand.

\subsection{Darwin and the Rise of Race Science}

Arnold represents, then, a version of an older theory couched in terms of the new vocabulary of "race," whose authority derives, in part, from its association with the increasing prestige of the natural sciences. (You will have noticed that in the excerpts from the Celtic literature lectures Arnold uses the word "data" several times.) And the most important theoretical development in the growth of a biological conception of race had already occurred by the time Arnold published Culture and Anarchy in 1869. For on November 24, 1859, Charles Darwin had published a work whose full title reads The Origin of Species by Means of Natural Selection or the Preservation of Favoured Races in the Struggle for Life.

The word "race" had been used in this way to refer to kinds of animals and plants, as well as to kinds of people, for some time; but there is no doubt that even for a mid-nineteenth-century ear this title promises something of relevance to the study of human difference. Indeed, the very fact that a single scientific theory promised to account for the variety of kinds of animals, in general, made its application to humans a natural step in the continuing process of placing the study of human anatomy in the context of a comparative zoology.

Darwin suggested, with characteristic caution, in The Origin of Species that his theory might throw light on "the origin of man and his history"; the implication being that human beings developed, like other modern organisms, out of earlier forms. Taken to its "logical conclusion" this view suggested the oneness not only of all human beings — related by common descent — but, at least potentially, the common ancestry, and thus unity, of all life. 
Darwin's theory can be thought of as consisting of two components: one is the claim that kinds of organisms develop by "descent with modification." ${ }^{49}$ This claim was immediately widely accepted and applied to understanding the classification of organisms, representing, as it did, a continuation of arguments made five decades earlier by Lamarck.

But Darwin's more distinctive claim was that the mechanism of modification was natural selection: the selective survival of characteristics that gave individuals advantages in the "struggle for life." Darwin here drew on the parallelism with artificial selection of animals that was carried on by horse and cattle breeders and by pigeon-fanciers. Just as they worked only with the natural variation among animals, selecting those with characteristics they favored and breeding from them, so, in Darwin's theory, nature "selected" organisms for breeding, not (as the rather colorful talk of the "struggle for life" suggested) by destroying some and allowing others to survive, but by affecting differentially rates of reproductive success.

This claim was not so easily accepted. To begin with it was not clear that there was sufficient variation within most kinds of organisms on which selection could work; and, indeed, though Darwin and Darwinians did stress the variability of natural populations, they had no account of the origin of the variations on which selection could act. More than this, most selective forces did not look as though they applied sufficient selection pressure to lead to any very substantial effects: it was only much later, with the development of population genetics, that it was possible to show that relatively small differences in survival rates could produce cumulatively large effects.

And, finally, Darwin had an inadequate and underdeveloped theory of inheritance: the modern account, in terms of the gene, had no real impact until after Mendel's work was rediscovered in 1900. The theory of evolution by natural selection required that

${ }^{49}$ My account here is based on Coleman, Biology in the Nineteenth Century. 
organisms should inherit the characteristics of their ancestors: otherwise the surviving offspring of an organism with a trait that gave it an advantage on the struggle for life offered no guarantee that its children would carry the same trait. Indeed, since Darwin believed in a sort of blending theory of inheritance, in which what accounted for a particular observable characteristic was the blended mixture of the factors that determined that characteristic in one's parents, he could not really explain why a factor that was rare in a population could survive at all, since it would be constantly "diluted" by more common forms.

There were other problems: if you want to treat all creatures as derived from a single ancient population, there must be some source of new variations: otherwise every characteristic in any modern organism must have existed in the earliest population. (Darwin was aware of "sports," creatures like the two-headed pigs to which I have already referred; but he thought — rightly, as it turns out - that these were of little importance in evolution.)

It is thus only with the development of Mendelism, with its account of inheritance in terms of genes, and its recognition of the possibility of new variety arising by mutation, that the theory of natural selection was placed on a sound footing.

This second part of Darwin's theory - the view of natural selection - was therefore rightly greeted with less immediate enthusiasm than the general idea of descent with modification.

Descent with modification was all that was required, however, to allow biology to give a much more straightforward account of how organisms should be classified. Darwin thought of species as essentially classificatory conveniences; $;{ }^{50}$ he was interested in how populations changed their character and separated from each other,

${ }^{50}$ See George W. Stocking, Race, Culture and Evolution (New York: Free Press, 1968): "Darwin's own position on the question of human races was equally congenial to polygenist thinking. Although he thought it a matter of indifference whether human races were called species or subspecies, he granted that a naturalist confronted for the first time with specimens of Negro and European man would doubtless call them 'good and true species' (p. 46). 
not in drawing boundaries between them. But his theory allowed that the accumulation of differences by selection could gradually produce kinds - varieties or species - that were measurably different and suggested a mode of classification in which kinds that were more closely related by evolution should be classified together.

Thus, the general acceptance of descent with modification and the increasing acceptance of Darwin's theory of natural selection gave scientific support to the idea that human kinds — races - like animal and plant species could be both evolutionarily related and biologically distinct. Furthermore, even though human races were not mutually infertile, the theory of evolution suggested a way of thinking of varieties as being in the process of speciation: races might not be species, but they were, so to speak, moving in that direction.

\subsection{The Problem for a Biology of Race}

Darwin, as I have said, thought of the species as essentially a classificatory convenience: he was, in philosophical jargon, a nominalist about species, holding that the boundaries between species were not clearly marked "in nature"; and if species were not marked in nature the varieties or subspecies (which is what, on his view, human races were), being even less distinct from each other than species, were presumably classificatory conveniences also.

To believe this was already to move away from the sort of racial essences that we find in Arnold. For Arnold, the interest of the characteristics of a race was exactly that you could suppose that its members all shared certain properties; so that having identified people's race membership from their appearance one could then make inferences about their moral or literary dispositions. It makes sense that Darwin, whose whole analysis depends on the recognition of variation within populations, was more interested in the ways individuals differed from each other within their varieties than in the ways they were similar.

Once we have the modern genetic picture we can see that each person is the product of enormous numbers of genetic characteris- 
tics, interacting with each other and with an environment, and that there is nothing in the theory of evolution to guarantee that a group that shares one characteristic will share all or even most others. Characteristics on different chromosomes are, as the Mendelians said, independently assorted. The theory of evolution will also predict that as you move through a geographical range along a gradient of selection pressure the frequency of certain characteristics - those that affect skin color, for example - may change fairly continuously, so that populations may blend into each other; and characteristics may drift from one neighboring population into another over time by intermarriage (or, to speak less euphemistically, interbreeding). Indeed, it turns out that, in humans, however you define the major races, the biological variability within them is almost as great as the biological variation within the species as a whole: put another way, while there are some characteristics that we are very good at recognizing - skin color, hair, skull shape - that are very unevenly geographically distributed, the groups produced by these assignments do not cluster much for other characteristics.

This fact was noticed by Ralph Waldo Emerson, only a few years after Arnold's essays. In 1876, in his essays on English Traits, he wrote:

An ingenious anatomist has written a book to prove that races are imperishable, ${ }^{51}$ but nations are pliant constructions, easily changed or destroyed. But this writer did not found his assumed races on any necessary law, disclosing their ideal or metaphysical necessity; nor did he on the other hand count with precision the existing races and settle the true bounds; a point of nicety, and the popular test of his theory. The individuals at the extremes of divergence in one race of men are as unlike as the wolf to the lapdog. Yet each variety shades down imperceptibly into the next, and you cannot draw the line where a race begins or ends. Hence every writer makes a different count. Blumenbach reckons five races; Humboldt three; and

\footnotetext{
${ }^{51}$ The reference is to Robert Knox's The Races of Men (1850).
} 
Mr. Pickering, who lately in our Exploring Expedition thinks he saw all kinds of men that can be on the planet, makes eleven. ${ }^{52}$

Even limiting oneself to the range of morphological criteria available to these comparative anatomists it is hard to classify people objectively into a small set of populations; and whichever way you do it, it will turn out that, for biological purposes, your classification will contain almost as much human genetic variation as there is in the whole species. ${ }^{53}$

"Race," then, as a biological concept, picks out, at best, among humans classes of people who share certain easily observable physical characteristics, most notably skin color and a few visible features of the face and head.

The materials for an evolutionary explanation for skin color variation are easily laid out. The original human population had dark skins, which give you a selective advantage in the tropics, because they protect you somewhat from skin cancer. Lighter skins developed in colder climes, no doubt in part because skin cancer is less of a problem where you are permanently clothed, because of the cold, and the sun's rays pass more obliquely through the atmosphere. There may have been actual selection for white skinsmaybe a landscape of mist and snow makes it easier to hide from your enemies - or it may just be that the mutations that make for white skin developed and survived because there was no longer selection pressure against them. ${ }^{54}$ This second possibility illustrates

${ }^{52}$ Ralph Waldo Emerson, English Traits (1876), vol. 5, Concord Edition (Boston and New York: Houghton Mifflin, 1904), pp. 44-45.

53 "On average there's .2 percent difference in genetic material between any two randomly chosen people on Earth. Of that diversity, 85 percent will be found within any local group of people - say, between you and your neighbor. More than half ( 9 percent) of the remaining 15 percent will be represented by differences between ethnic and linguistic groups within a given race (for example, between Italians and French). Only 6 percent represents differences between races (for example, between Europeans and Asians). And remember that's 6 percent of .2 percent. In other words, race accounts for only a minuscule .012 percent difference in our genetic material" (Paul Hoffman, "The Science of Race," Discover [November 19941, 4).

${ }^{54}$ See Bernard R. Ortiz de Montellano, "Melanin, Afrocentricity and Pseudoscience," Yearbook of Physical Anthropology 36 (1993), 33-57. 
a form of evolutionary change that is of some importancenamely, the development of populations whose character is the result not of adaptation but of the presence, by chance, in an isolated environment of a particular nonrepresentative sample of the total gene pool. And we may as well mention a third possibility here, one that Darwin noticed as well, which is that skin color was maintained by sexual selection: because, for some reason or other, human beings of one sex or other (or both) developed a preference for mates with lighter skins.

Why does biological variation in skin color not correlate more with other characteristics? Partly, because the other characteristics have been selected (as has, say, sickle-cell disease, in parts of West Africa and the eastern Mediterranean) under pressures not highly correlated with the presence of harmful amounts of sunlight. Perhaps, too, because there are mechanisms that have evolved to maintain the stability of the genotype, reflecting, among other things, the fact that certain combinations of genes are adaptive only when they are present together. ${ }^{55}$ As a result, even after long periods of the order of hundreds of thousands of years - of geographical separation, human populations do not drift apart significantly with respect to most of their biological properties. And, finally, because there has been continuous exchange of genes among the major geographical areas of human settlement over the hundreds of thousands of years since the first humans set off out of Africa.

The United States bears witness to the continuing significance of this phenomenon. It is true that Americans still tend, overwhelmingly, to marry people of their own, as we say, "racial identity." But very large numbers (perhaps as many as two-thirds) of African-Americans have some European forebears; up to twofifths may have American Indian "blood"; and at least 5 percent of white Americans are thought to have African roots. It is estimated that 20 to 30 percent of the genes of the average African-

${ }^{55}$ Ernst Mayr, Populations, Species and Evolution (Cambridge: Harvard University Press, 1970), p. 300. 
American come from European and American Indian ancestors. ${ }^{56}$ The result is that, even if the four roughly separated populations of the four continents from which the ancestors of most Americans came had each been much less genetically variable than was in fact the case, there would still be large numbers of people whose skin color predicts very few other biological properties.

\subsection{Why There Are No Races}

We have followed enough of the history of the race concept and said enough about current biological conceptions to answer, on both ideational and referential view, the question whether there are any races.

On the ideational view, the answer is easy. From Jefferson to Arnold, the idea of race has been used, in its application to humans, in such a way as to require that there be significant correlations between the biological and the moral, literary, or psychological characters of human beings; and that these be explained by the intrinsic nature (the "talents" and "faculties" in Jefferson; the "genius," in Arnold) of the members of the race. ${ }^{57}$

That has turned out not to be true, the recent fuss generated by The Bell Curve about the correlation of race and IQ in the United States notwithstanding. Even if you believed Charles Murray and Richard Herrnstein's estimates of the heritability of IQ within groups in the United States - and you shouldn't - they offer almost no evidence relevant to refuting the claim that the differences between American groups are entirely caused by the environment - say, in particular, by the ways that blacks are treated in a racist society. ${ }^{58}$

${ }^{56}$ James Shreve, “Terms of Estrangement," Discover (November 1994), 58. All these claims should be interpreted bearing in mind the fact that a "recent study found that in the early 1970s, 34 percent of the people participating in a census survey in two consecutive years changed racial groups from one year to the next" (ibid.).

${ }^{57}$ That is, not produced by the fact that people who have certain physical appearances are treated in ways that produce differences.

${ }^{58}$ Since this point is elementary it is perhaps worth explaining. Heritability measures the ratio of variance in a characteristic in an environment that is due to 
Once you have the modern theory of inheritance, you can see why there is less correlation than everyone expected between skin color and things we care about: people are the product not of essences but of genes interacting with each other and with environments and there is little systematic correlation between the genes that fix color and the like and the genes that fix courage or literary genius. So, to repeat, on the ideational view we can say that nothing in the world meets the criteria for being a Jeffersonian or an Arnoldian race.

The biological notion of race was meant to account only for a narrow range of characteristics, namely, the biological ones, by which I mean the ones important for biological theory. There are certainly many ways of classifying people for biological purposes: but there is no single way of doing so that is important for most biological purposes that corresponds, for example, to the majority populations of each continent or subcontinent. It follows that on an ideational view, there are no biological races either: not, in this case, because nothing fits the loose criteria, but because too many things do. ${ }^{59}$

On the referential view we are required to find something in the world that best explains the history of usage of the term. Two candidates suggest themselves for the biological uses of "race": one is the concept of a population that I have been using for a while now. It can be defined as "the community of potentially

genes to the total variance. The heritability of height in the United States, in India, and in the human population in general is high. There is, too, a significant difference in average height between Indians (in India) and Americans (in America). But this interpopulational difference is almost entirely due to differences in nutrition. High heritability is quite consistent with most of the difference between populations being environmental.

Herrnstein and Murray, authors of The Bell Curve (New York: Free Press, 1994), are aware of this fact and so seek to offer some rather unconvincing arguments for the suspicion that interracial average differences are in fact significantly genetic in origin. For arguments that they are not, see chapter 6 of Thomas Sowell's Race and Culture: A World View (New York: Basic Books, 1994).

${ }^{59}$ This is essentially the point of Jared Diamond's essay "Race without Color," Discover (November 1994), 82-89. 
interbreeding individuals at a given locality." ${ }^{60}$ There are interesting discussions in the literature in population genetics as to how one should think about where to draw the boundaries of such communities: sometimes there is geographic isolation, which makes interbreeding in the normal course of things much less likely. But the population concept is generally used in such a way that we speak sometimes of a population defined by one geographical region and also, at other times, of a wider population, defined by a wider range, of which the first population is a part; and at yet other times of populations that are overlapping.

I have no problem with people who want to use the word "race" in population genetics. ${ }^{61}$ What Darwin was talking aboutevolution, speciation, adaptation — can best be understood in terms of talk of populations. And the fact is that in many plants and animals there are, in fact, local populations that are reproductively isolated from each other, different in clustered and biologically interesting ways, and still capable of interbreeding if brought artificially together; and biologists both before and after Darwin could have called these "races." It's just that this doesn't happen in human beings. In this sense, there are biological races in some creatures, but not in us.

A more ecumenical proposal in this spirit would be to say that the word "race" refers to populations, more generally. The trouble is that, in this sense, while there are human populations that are and have been for some time relatively reproductively isolated, it is not at all plausible to claim that any social subgroup in the United States is such a population. In this sense, then, there are human races, because there are human populations, in the geneti-

${ }^{60}$ Mayr, Populations, Species and Evolution, p. 82.

${ }^{61}$ I think, however, that this usage carries two risks: first, it gives an illdeserved legitimacy to ideas that are mistaken, because those who listen in to these conversations may not be aware of the fact that the usage here does not correspond at all to the groups that have mostly been called races in Europe and America; second, because by speaking this way, you can actually find yourself relying, illicitly, on those other modes of classification. Still, if you can avoid these two dangers, there's no problem. 
cists' sense, but no large social group in America is a race. (The Amish, however, might come out as a race on this view, since they are a relatively reproductively isolated local population.)

A second candidate for the biological referent would simply be groups defined by skin color, hair, and gross morphology, corresponding to the dominant pattern for these characteristics in the major subcontinental regions: Europe, Africa, East and South Asia, Australasia, the Americas, and, perhaps, the Pacific Islands. This grouping would encompass many human beings quite adequately and some not at all: but it is hard to see of what biological interest it would be, since we can study the skin and gross morphology separately, and there is, at any rate, a good deal of variation within all these areas, in skin, hair color, and the morphology of the skull. Certainly, this referent would not provide us with a concept that was central to biological thinking about human beings. And once more, in the United States, large numbers of people would not fit into any of these categories, because they are the products of mixtures (sometimes long ago) between people who do roughly fit this pattern, even though the social distinctions we call "racial" in the United States do, by contrast, cover almost everybody. And so, if we used this biological notion, it would have very little established correlation with any characteristics currently thought to be important for moral or social life.

The bottom line is this: you can't get much of a race-concept, ideationally speaking, from any of these traditions; you can get various possible candidates from the referential notion of meaning, but none of them will be much good for explaining social or psychological life, and none of them corresponds to the social groups we call "races" in America. 


\section{Part 2. Synthesis: For Racial Identities}

\section{1 "Speaking Of Civilizations"}

In 1911, responding to what was already clear evidence that race was not doing well as a biological concept, W. E. B. Du Bois, the African-American sociologist, historian, and activist, wrote in the Crisis, the magazine of the NAACP, which he edited:

The leading scientists of the world have come forward ... and laid down in categorical terms a series of propositions which may be summarized as follows $:^{62}$

1. (a) It is not legitimate to argue from differences in physical characteristics to differences in mental characteristics ...

2 . The civilization of a . . race at any particular moment of time offers no index to its innate or inherited capacities. ... ${ }^{63}$

And he concluded: "So far at least as intellectual and moral aptitudes are concerned we ought to speak of civilizations where we now speak of races." ${ }^{64}$ I have argued before that Du Bois's proposal to "speak of civilizations" turns out not to replace a biological notion but simply to hide it from view. ${ }^{65}$ I think there are various difficulties with the way that argument proceeded, and I should like to do better. So let me try to reconstruct a sociohistorical view that has more merit than I have previously conceded.

${ }^{62}$ This claim was prompted by G. Spiller, (ed.), Papers in Inter-Racial Problems Communicated to the First Universal Races Congress Held at the University of London, July 26-29, 1911 (London: P. S. King and Son, 1911), republished with an introduction by H. Aptheker (Secaucus, N.J.: Citadel Press, 1970).

${ }^{63}$ W. E. B. Du Bois, "Races," in Writings in Periodicals Edited by W.E. B. Du Bois, Vol. 1, 1911-1925, compiled and edited by Herbert Aptheker (Milwood, N.Y.: Kraus-Thomson Organization, 1983), p. 13.

${ }^{64}$ Ibid., p. 14.

65 "The Uncompleted Argument: Du Bois and the Illusion of Race," reprinted from Critical Inquiry 12 (Autumn 1985), in "Race," Writing and Difference ed. Henry Louis Gates, Jr. (Chicago: University of Chicago Press, 1986), pp. 21-37. Lucius Outlaw has remonstrated with me about this in the past; these rethinkings are largely prompted by discussion with him. 
Among the most moving of $\mathrm{Du}$ Bois's statements of the meaning of "race" conceived in sociohistorical terms is the one in Dusk of Dawn, the "autobiography of a race concept," as he called it, which he published in 1940. Du Bois wrote:

The actual ties of heritage between the individuals of this group, vary with the ancestors that they have in common with many others: Europeans and Semites, perhaps Mongolians, certainly American Indians. But the physical bond is least and the badge of color relatively unimportant save as a badge; the real essence of this kinship is its social heritage of slavery; the discrimination and insult; and this heritage binds together not simply the children of Africa, but extends through yellow Asia and into the South Seas. It is this unity that draws me to Africa. $^{66}$

For reasons I shall be able to make clear only when I have given my account, $\mathrm{Du}$ Bois's own approach is somewhat misleading. So rather than proceeding with exegesis of $\mathrm{Du}$ Bois, I must turn next to the task of shaping a sociohistorical account of racial identity. Still, as it turns out, it is helpful to start from Du Bois's idea of the "badge of color."

\subsection{Racial Identity And Racial Identification}

I have argued that Jefferson and Arnold thought that when they applied a racial label they were identifying people with a shared essence. ${ }^{67}$ I have argued, also, that they were wrong; and, I insist, not slightly but wildly wrong. Earlier in American history, the label "African" was applied to many of those who would later be thought of as Negroes, by people who may have been under the

${ }^{66}$ W. E. B. Du Bois, Dusk of Dawn: An Essay toward an Autobiography of a Race Concept (New York: Harcourt, Brace and Company, 1940), reprinted with introduction by Herbert Aptheker (Milwood, N.Y.: Kraus-Thomson Organization, 1975), pp. 116-17.

${ }^{67} \mathrm{I}$ am conscious here of having been pushed to rethink my views by Stuart Hall's Du Bois lectures at Harvard in the spring of 1994, which began with a nuanced critique of my earlier work on Du Bois's views. 
impression that Africans had more in common culturally, socially, intellectually, religiously, than they actually did. Neither of these kinds of errors, however, stopped the labeling from having its effects. As slavery in North America became racialized in the colonial period, being identified as an African, or, later, as a Negro, carrying the "badge of color," had those predictable negative consequences that $\mathrm{Du}$ Bois so memorably captured in the phrase the "social heritage of slavery; the discrimination and insult."

If we follow the badge of color, from "African" to "Negro" to "Colored Race" to "Black" to "Afro-American" to "AfricanAmerican" (and this ignores such fascinating detours as the route by way of "Afro-Saxon") we are thus tracing the history not only of a signifier, a label, but also a history of its effects. At any time in this history there was, within the American colonies and the United States that succeeded them, a massive consensus, both among those labeled black and among those labeled white, as to who, in their own communities, fell under which labels. (As immigration from China and other parts of the "Far East" occurred, an "Oriental" label came to have equal stability.) There was, no doubt, some "passing"; but the very concept of passing implies that, if the relevant fact about the ancestry of these individuals had become known, most people would have taken them to be traveling under the wrong badge.

The major North American exception was in southern Louisiana, where a different system in which an intermediary, Creole, group, neither white nor black, had social recognition; but Plessy v. Fergusson reflected the extent to which the Louisiana Purchase effectively brought even that state gradually into the American mainstream of racial classification. For in that case Homer Adolph Plessy - a Creole gentleman who could certainly have passed in most places for white - discovered in 1896, after a long process of appeal, that the Supreme Court of the United States proposed to treat him as a Negro and, therefore, recognize the State of Louisiana's right to keep him "separate but equal" from whites. 
The result is that there are at least three sociocultural objects in America - Blacks, Whites, and Orientals - whose membership at any time is relatively - and increasingly — determinate. These objects are historical in this sense: to identify all the members of these American races over time, you cannot seek a single criterion that applies equally always; you can find the starting point for the race - the subcontinental source of the population of individuals that defines its initial membership — and then apply at each historical moment the criteria of intertemporal continuity that apply at that moment to decide which individuals in the next generation count as belonging to the group. There is from the very beginning until the present, at the heart of the system, a simple rule that very few would dispute even today: Where both parents are of a single race, the child is of the same race as the parents.

The criteria applicable at any time may leave vague boundaries. They certainly change, as the varying decisions about what proportion of African ancestry made one black or the current uncertainty as to how to assign the children of White-Yellow "miscegenation" demonstrates. But they always definitely assign some people to the group and definitely rule out others; and, for most of America's history, the class of people about whom there was uncertainty (are the Florida Seminoles black or Indian ?) was relatively small. ${ }^{68}$

Once the racial label is applied to people, ideas about what it refers to, ideas that may be much less consensual than the application of the label, come to have their social effects. But they have not only social effects but psychological effects as well: and they shape the ways people conceive of themselves and their projects. In particular, the labels can operate to shape what I want to call identification: the process through which an individual intentionally shapes her projects -including her plans for her own life and her conception of the good - by reference to available labels, available identities.

${ }^{68}$ See Kevin Mulroy, Freedom on the Border: The Seminole Maroons in Florida, the Indian Territory, Coahuila, and Texas (Lubbock: Texas Tech University Press, 1993). 
Identification is central to what Ian Hacking has called "Making Up People." " Drawing on a number of examples, but centrally homosexuality and multiple personality syndrome, he defends what he calls a "dynamic nominalism," which argues "that numerous kinds of human beings and human acts come into being hand in hand with our invention of the categories labeling them." ${ }^{70}$ I have just articulated a dynamic nominalism about a kind of person that is currently usually called "African-American."

Hacking reminds us of the philosophical truism, whose most influential formulation is in Elizabeth Anscombe's work on intention, that, in intentional action, people act "under descriptions"; that their actions are conceptually shaped. It follows, of course, that what people can do depends on what concepts they have available to them; and among the concepts that may shape one's action is the concept of a certain kind of person and the behavior appropriate to that kind.

Hacking offers as an example Sartre's brilliant evocation, in Being and Nothingness, of the Parisian garçon de café:

His movement is quick and forward, a little too precise, a little rapid. He comes towards the patrons with a step a little too quick. He bends forward a little too eagerly, his eyes express an interest too solicitous for the order of the customer. ${ }^{71}$

Hacking comments:

Sartre's antihero chose to be a waiter. Evidently that was not a possible choice in other places, other times. There are servile people in most societies, and servants in many, but a waiter is something specific, and a garçon de café more specific.

${ }^{69}$ Ian Hacking, "Making Up People," reprinted from Reconstructing Individualism: Autonomy, Individuality and the Self in Western Thought, ed. Thomas Heller, Morton Sousa, and David Wellbery (Stanford: Stanford University Press, 1986), in Forms of Desire: Sexual Orientation and the Social Constructionist Controversy, ed. Edward Stein (New York: Routledge, 1992), pp. 69-88 (page references are to this version).

${ }^{70}$ Hacking, "Making Up People," p. 87.

${ }^{71}$ Cited in ibid., p. 81 . 
... As with almost every way in which it is possible to be a person, it is possible to be a garçon de café only at a certain time, in a certain place, in a certain social setting. The feudal serf putting food on my lady's table can no more choose to be a garçon de café than he can choose to be lord of the manor. But the impossibility is evidently of a different kind. ${ }^{72}$

The idea of the garçon de café lacks, so far as I can see, the sort of theoretical commitments that are trailed by the idea of the black and the white, the homosexual and the heterosexual. So, it makes no sense to ask of someone who has a job as a garçon de café whether that is what he really is. The point is not that we do not have expectations of the garçon de café: that is why it is a recognizable identity. It is rather that those expectations are about the performance of the role; they depend on our assumption of intentional conformity to those expectations. As I spent some time arguing earlier, we can ask whether someone is really of a black race, because the constitution of this identity is generally theoretically committed: we expect people of a certain race to behave a certain way not simply because they are conforming to the script for that identity, performing that role, but because they have certain antecedent properties that are consequences of the label's properly applying to them. It is because ascription of racial identities - the process of applying the label to people, including ourselves - is based on more than intentional identification that there can be a gap between what people ascriptively are and the racial identity they perform: it is this gap that makes passing possible.

Race is, in this way, like all the major forms of identification that are central to contemporary identity politics: female and male; gay, lesbian, and straight; black, white, yellow, red, and brown; Jewish-, Italian-, Japanese-, Korean-American; even that most neglected of American identities, class. There is, in all of them, a

\footnotetext{
${ }^{72}$ Ibid., p. 82 .
} 
set of theoretically committed criteria for ascription, not all of which are held by everybody, and which may not be consistent with each other even in the ascriptions of a single person; and there is then a process of identification in which the label shapes the intentional acts of (some of) those who fall under it.

It does not follow from the fact that identification shapes action, shapes life-plans, that the identification itself must be thought of as voluntary. I don't recall ever choosing to identify as a male, ${ }^{73}$ but being-male has shaped many of my plans and actions. In fact, where my ascriptive identity is one on which almost all of my fellow-citizens agree, I am likely to have little sense of choice about whether the identity is mine; though I can choose how central my identification with it will be, choose, that is, how much I will organize my life around that identity. Thus, if I am among those (like the unhappily labeled "straight-acting gay men" or most American Jews) who are able, if they choose, to escape ascription, I may choose not to take up a gay or a Jewish identity, though this will require concealing facts about myself or my ancestry from others.

If, however, I fall into the class of those for whom the consensus on ascription is not clear - as among contemporary socalled bi-racials or bisexuals, or those many white Americans of multiple identifiable ethnic heritages ${ }^{74}$ - I may have a sense of identity options: but one way I may exercise them is by marking myself ethnically (as when someone chooses to wear an Irish pin) so that others will then be more likely to ascribe that identity to me.

\subsection{Differences among Differences}

Collective identities differ, of course, in lots of ways; the body is central to race, gender, and sexuality, but not so central to class and ethnicity. And, to repeat an important point, racial identifica-

${ }^{73}$ That I don't recall it doesn't prove that I didn't, of course.

${ }^{74}$ See Mary C. Waters, Ethnic Options: Choosing Identities in America (Berkeley: University of California Press, 1990). 
tion is simply harder to resist than ethnic identification. The reason is twofold. First racial ascription is more socially salient: unless you are morphologically atypical for your racial group, strangers, friends, and officials are always aware of it in public and private contexts, always notice it, almost never let it slip from view. Second - and again both in intimate settings and in public space - race is taken by so many more people to be the basis for treating people differentially. (In this respect, Jewish identity in America strikes me as being a long way along a line toward AfricanAmerican identity: there are ways of speaking and acting and looking - and it matters very little whether they are "really" mostly cultural or mostly genetic — associated with being Jewish; and there are many people, white and black, Jewish and Gentile, from whom this identity is a cultural force in shaping their responses to others.)

This much about identification said, we can see that Du Bois's analytical problem was, in essence, that he believed that for racial labeling of this sort to have the obvious real effects that it did have - among them, crucially, his own identification with other black people and with Africa - there must be some real essence that held the race together. Our account of the history of the label reveals that this is a mistake: once we focus, as Du Bois almost saw, on the racial badge - the signifier rather than the signified, the word rather than the concept - we see both that the effects of the labeling are powerful and real and that false ideas, muddle and mistake and mischief, played a central role in determining both how the label was applied and to what purposes.

This, I believe, is why Du Bois so often found himself reduced, in his attempts to define race, to occult forces: if you look for a shared essence you won't get anything, so you'll come to believe you've missed it, because it is supersubtle, difficult to experience or identify: in short, mysterious. But if, as I say, you understand the sociohistorical process of construction of the race, you'll see that the label works despite the absence of an essence. 
Perhaps, then, we can allow that what Du Bois was after was the idea of racial identity, which I shall roughly define as

a label, $R$,

associated with ascriptions by most people (where ascription involves descriptive criteria for applying the label); and

identifications by those that fall under it (where identification implies a shaping role for the label in the intentional acts of the possessors, so that they sometimes act as an $R$ );

where there is a history of associating possessors of the label with an inherited racial essence (even if some who use the label no longer believe in racial essences).

In fact, we might argue that racial identities could persist even if nobody believed in racial essences, provided both ascription and identification continue.

There will be some who will object to my account that it does not give racism a central place in defining racial identity: it is obvious, I think, from the history I have explored, that racism has been central to the development of race-theory. In that sense racism has been part of the story all along. But you might give an account of racial identity in which you counted nothing as a racial essence unless it implied a hierarchy among the races $^{75}$; or unless the label played a role in racist practices. I have some sympathy with the former strategy; it would fit easily into my basic picture. To the latter strategy, however, I make the philosopher's objection that it confuses logical and causal priority: I have no doubt that racial theories grew up, in part, as rationalizations for mistreating Blacks, Jews, Chinese, and various others. But I think it is useful to reserve the concept of racism, as opposed to ethnocentrism or simply inhumanity, for practices in which a race-concept plays a central role. And I doubt you can explain racism without first explaining the race-concept.

${ }^{75}$ This is the proposal of a paper on "Metaphysical Racism" by Berel Lang at the New School for Social Research seminar on "Race and Philosophy" in October 1994, from which I learned much. 
I a $m$ in sympathy, however, with an animating impulse behind such proposals: which is to make sure that here in America we do not have discussions of race in which racism disappears from view. As I pointed out, racial identification is hard to resist in part because racial ascription by others is so insistent; and its effects especially the racist ones - are so hard to escape. It is obvious, I think, that the persistence of racism means that racial ascriptions have negative consequences for some and positive consequences for others - creating, in particular, the white skin privilege that it is so easy for people who have it to forget; and it is clear, too, that for those who suffer from the negative consequences, racial identification is a predictable response, especially where the project it suggests is that the victims of racism should join together to resist it. I shall return later to some of the important moral consequences of present racism and the legacy of racisms of the past.

But before I do, I want to offer an argument against substituting for an understanding of racial identity, such as mine, that places inherited racial essences at its heart, some newer accounts that see racial identity as a species of cultural identity.

\subsection{Cultural Identity in an Age of Multiculturalism}

Most contemporary racial identification - whether it occurs in such obviously regressive form as the white nationalism of the Aryan Nation or in an Afrocentrism about which, I believe, a more nuanced position is appropriate - most naturally expresses itself in forms that adhere to modified (and sometimes unreconstructed) versions of the old racial essences. But the legacy of the Holocaust and the old racist biology has led many to be wary of racial essences and to replace them with cultural essences. Before I turn to my final cautionary words about racial identifications, I want to explore, for a moment, the substitution of cultures for races that has occurred in the movement for multiculturalism.

In my dictionary I find as a definition for "culture": "The totality of socially transmitted behavior patterns, arts, beliefs, in- 
stitutions, and all other products of human work and thought." 76 Like most dictionary definitions, this is, no doubt, a proposal on which one could improve. But it surely picks out a familiar constellation of ideas. That is, in fact, the sense in which anthropologists largely use the term nowadays. The culture of the Asante or the Zuni, for the anthropologist, includes every object they makematerial culture - and everything they think and do.

The dictionary definition could have stopped there, leaving out the talk of "socially transmitted behavior patterns, arts, beliefs, institutions" because these are all products of human work and thought. They are mentioned because they are the residue of an older idea of culture than the anthropological one; something more like the idea we might now express with the word "civilization": the "socially transmitted behavior patterns" of ritual, etiquette, religion, games, arts; the values that they engender and reflect; and the institutions - family, school, church, state - that shape and are shaped by them. ${ }^{77}$ The habit of shaking hands at meetings belongs to culture in the anthropologist's sense; the works of Sandro Botticelli and Martin Buber and Count Basie belong to culture also, but they belong to civilization as well.

There are tensions between the concepts of culture and of civilization. There is nothing, for example, that requires that an American culture should be a totality in any stronger sense than being the sum of all the things we make and do.

American civilization, by contrast, would have to have a certain coherence. Some of what is done in America by Americans would not belong to American civilization because it was too in-

${ }^{76}$ American Heritage Dictionary III for DOS, 3rd edition (Novato, Calif.: Wordstar International, 1993).

${ }^{77}$ The distinction between culture and civilization I am marking is not one that would have been thus marked in nineteenth-century ethnography or (as we would now say) social anthropology: culture and civilization were basically synonyms and they were both primarily used in the singular. The distinctions I am making draw on what I take to be the contemporary resonances of these two words. If I had more time, I would explore the history of the culture-concept the sort of way we have explored race. 
dividual (the bed-time rituals of a particular family); some would not belong because it was not properly American, because (like a Hindi sentence, spoken in America) it does not properly cohere with the rest.

The second, connected, difference between culture and civilization is that the latter takes values to be more central to the enterprise, in two ways. First, civilization is centrally defined by moral and aesthetic values: and the coherence of a civilization is, primarily, the coherence of those values with each other and, then, of the group's behavior and institutions with its values. Second, civilizations are essentially to be evaluated: they can be better and worse, richer and poorer, more and less interesting. Anthropologists, on the whole, tend now to avoid the relative evaluation of cultures, adopting a sort of cultural relativism, whose coherence philosophers have tended to doubt. And they do not take values as more central to culture than, for example, beliefs, ideas, and practices.

The move from "civilization" to "culture" was the result of arguments. The move away from evaluation came first, once people recognized that much evaluation of other cultures by the Europeans and Americans who invented anthropology had been both ignorant and biased. Earlier criticisms of "lower" peoples turned out to involve crucial misunderstandings of their ideas; and it eventually seemed clear enough, too, that nothing more than differences of upbringing underlay the distaste of some Westerners for unfamiliar habits. It is a poor move from recognizing certain evaluations as mistaken to giving up evaluation altogether, and anthropologists who adopt cultural relativism often preach more than practice it. Still, this cultural relativism was a response to real errors. That it is the wrong response doesn't make the errors any less erroneous.

The arguments against "civilization" were in place well before the mid-century. More recently, anthropologists began to see that the idea of the coherence of a civilization got in the way of understanding important facts about other societies (and, in the end, 
about our own). For even in some of the "simplest" societies, there are different values and practices and beliefs and interests associated with different social groups (for example, women as opposed to men). To think of a civilization as coherent was to miss the fact that these different values and beliefs were not merely different but actually opposed. Worse, what had been presented as the coherent, unified worldview of a tribal people often turned out, on later inspection, to be merely the ideology of a dominant group or interest.

But the very idea of a coherent structure of beliefs and values and practices depends on a model of culture that does not fit our times, as we can see if we explore, for a moment, the ideal type of a culture where it might seem to be appropriate.

\subsection{A Common Culture}

There is an ideal — and thus, to a certain extent, imaginary type of a small-scale, technologically uncomplicated, face-to-face society, where most interactions are with people whom you know, that we call "traditional." In such a society every adult who is not mentally disabled speaks the same language. All share a vocabulary and a grammar and an accent. While there will be some words in the language that are not known by everybody - the names of medicinal herbs, the language of some religious rituals most are known to all normal adults. To share a language is to participate in a complex set of mutual expectations and understandings: but in such a society it is not only linguistic behavior that is coordinated through universally known expectations and understandings. People will share an understanding of many practices - marriages, funerals, other rites of passage - and will largely share their views about the general workings not only of the social but also of the natural world. Even those who are skeptical about particular elements of belief will nevertheless know what everyone is supposed to believe, and they will know it in enough detail to behave very often as if they believed it, too. 
A similar point applies to many of the values of such societies. It may well be that some people, even some groups, do not share the values that are enunciated in public and taught to children. But, once more, the standard values are universally known and even those who do not share them know what it would be to act in conformity with them and probably do so much of the time.

In such a traditional society we may speak of these shared beliefs, values, signs, and symbols as the common culture; not, to insist on a crucial point, in the sense that everyone in the group actually holds the beliefs and values, but in the sense that everybody knows what they are and everybody knows that they are widely held in the society.

Now the citizens of one of those large "imagined communities" of modernity we call "nations" need not have, in this sense, a common culture. There is no single shared body of ideas and practices in India, or, to take another example, in most contemporary African states. And there is not now and there has never been a common culture in the United States, either. The reason is simple: the United States has always been multilingual and has always had minorities who did not speak or understand English. It has always had a plurality of religious traditions; beginning with American Indian religions and Puritans and Catholics and including now many varieties of Judaism, Islam, Buddhism, Jainism, Taoism, Bahai, and so on. And many of these religious traditions have been quite unknown to each other. More than this, Americans have also always differed significantly even among those who do speak English, from North to South and East to West, and from country to city, in customs of greeting, notions of civility, and a whole host of other ways. The idea that what has held the United States together historically over its great geographical range is a common culture, like the common culture of my traditional society, is — to put it politely — not sociologically plausible.

The observation that there is no common American national culture will come as a surprise to many: observations about Amer- 
ican culture, taken as a whole, are widespread. It is, for example, held to be individualist, litigious, racially obsessed. I think each of these claims is actually true, because what I mean when I say there is no common culture of the United States is not what is denied by someone who says that there is an American culture.

Such a person is describing large-scale tendencies within American life that are not necessarily participated in by all Americans. I do not mean to deny that these exist. But for such a tendency to be part of what I am calling the common culture they would have to derive from beliefs and values and practices (almost) universally shared and known to be so. And that they are not.

At the same time, it has also always been true that there was a dominant culture in these United States. It was Christian, it spoke English, and it identified with the high cultural traditions of Europe and, more particularly, of England. This dominant culture included much of the common culture of the dominant classes the government and business and cultural elites: but it was familiar to many others who were subordinate to them. And it was not merely an effect but also an instrument of their domination.

The United States of America, then, has always been a society of many common cultures, which I will call, for convenience, subcultures (noting, for the record, that this is not the way the word is used in sociology).

It would be natural, in the current climate, with its talk of multiculturalism, to assume that the primary subgroups to which these subcultures are attached will be ethnic and racial groups (with religious denominations conceived of as a species of ethnic group). It would be natural, too, to think that the characteristic difficulties of a multicultural society arise largely from the cultural differences between ethnic groups. I think this easy assimilation of ethnic and racial subgroups to subcultures is to be resisted.

First of all, it needs to be argued, and not simply assumed, that black Americans, say, taken as a group, have a common culture: values and beliefs and practices that they share and that they do 
not share with others. This is equally true for, say, ChineseAmericans; and it is a fortiori true of white Americans. What seems clear enough is that being an African-American or AsianAmerican or White is an important social identity in the United States. Whether these are important social identities because these groups have shared common cultures is, on the other hand, quite doubtful; not least because it is doubtful whether they have common cultures at all.

The issue is important because an analysis of America's struggle with difference as a struggle among cultures suggests a mistaken analysis of how the problems of diversity arise. With differing cultures, we might expect misunderstandings arising out of ignorance of each other's values, practices, and beliefs; we might even expect conflicts because of differing values or beliefs. The paradigms of difficulty in a society of many cultures are misunderstandings of a word or a gesture; conflicts over who should take custody of the children after a divorce; whether to go to the doctor or the priest for healing.

Once we move from talking of cultures to identities whole new kinds of problems come into view. Racial and ethnic identities are, for example, essentially contrastive and relate centrally to social and political power; in this way they are like genders and sexualities.

Now it is crucial to understanding gender and sexuality that women and men and gay and straight people grow up together in families, communities, denominations. Insofar as a common culture means common beliefs, values, and practices, gay people and straight people in most places have a common culture: and while there are societies in which the socialization of children is so structured by gender that women and men have seriously distinct cultures, this is not a feature of most "modern" societies. And it is perfectly possible for a black and a white American to grow up together in a shared adoptive family — with the same knowledge and values - and still grow into separate racial identities, in part 
because their experience outside the family, in public space, is bound to be racially differentiated.

I have insisted that we should distinguish between cultures and identities: but ethnic identities characteristically have cultural distinctions as one of their primary marks. That is why it is so easy to conflate them. Ethnic identities are created in family and community life. These-along with mass-mediated culture, the school, and the college - are, for most of us, the central sites of the social transmission of culture. Distinct practices, ideas, norms go with each ethnicity in part because people want to be ethnically distinct: because many people want the sense of solidarity that comes from being unlike others. With ethnicity in modern society, it is often the distinct identity that comes first and the cultural distinction that is created and maintained because of it, not the other way around. The disinctive common cultures of ethnic and religious identities matter not simply becasue of their contents but also as markers of those identities.

In the United States, not only ethnic but also racial boundaries are culturally marked. In White Women, Race Matters: The Social Construction of Whiteness, ${ }^{78}$ Ruth Frankenberg records the anxiety of many white women who do not see themselves as white "ethnics" and worry, therefore, that they have no culture. ${ }^{79}$ This is somewhat puzzling in people who live, as every normal human being does, in rich structures of knowledge, experience, value, and meaning, through tastes and practices: it is perplexing, in short, in people with normal human lives. But the reason these women do not recognize that they have a culture is because none of these things that actually make up their cultural lives are marked as white, as belonging specially to them: and the things that are marked as white (racism, white privilege) are things they want to

78 Ruth Frankenberg, White Women, Race Matters: The Social Construction of Whiteness ( Minneapolis: University of Minnesota Press, 1993).

79 This discussion is shaped by conversation with Larry Blum, Martha Minow, David Wilkins, and David Wong, who will nevertheless not, I suspect, agree with what I say. 
repudiate. Many African-Americans, by contrast, have cultural lives in which the ways they eat, the churches they go to, the music they listen to, and the ways they speak are marked as black: their identities are marked by cultural differences.

I have insisted that African-Americans do not have the same culture, in the sense of shared language, values, practices, and meanings. But many people who think of races as groups defined by shared cultures conceive that sharing in a different way. They understand black people as sharing black culture by definition: jazz or hip-hop belongs to an African-American, whether she likes it or knows anything about it, because it is culturally marked as black. Jazz belongs to a black person who knows nothing about it more fully or naturally than it does to a white jazzman.

\subsection{What Matters about Culture: Arnold Again}

This view is an instance of what my friend Skip Gates has called "cultural geneticism." ${ }^{80}$ It has, in Bertrand Russell's wicked phrase, "the virtues of theft over honest toil." On this view, you earn rights to culture that is marked with the mark of your race or your nation - simply by having a racial identity. For the old racialists, as we saw, your racial character was something that came with your essence; this new view recognizes that race does not bring culture, and generously offers, by the wave of a wand, to correct nature's omission. It is as generous to Whites as it is to Blacks. Because Homer and Shakespeare are products of Western culture, they are awarded to white children who have never studied a word of them, never heard their names. And in this generous spirit the fact is forgotten that cultural geneticism deprives white people of jazz and black people of Shakespeare. This is a bad deal: as $\mathrm{Du}$ Bois would have insisted. "I sit with Shakespeare," the Bard of Great Barrington wrote, "and he winceth not." 
There is nothing in cultural geneticism of the ambition or the rigor of Matthew Arnold's conception, where culture is, as he says in Culture and Anarchy, "the disinterested and active use of reading, reflection and observation," ${ }^{81}$ and what is most valuable to us in culture, in the anthropological sense, is earned by intellectual labor, by self-cultivation. For Arnold true culture is a process "which consists in becoming something rather than in having something, in an inward condition of the mind and spirit," 82 whose aim is a "perfection in which characters of beauty and intelligence are both present, which unites 'the two noblest of things,' - as Swift, who of one of the two, at any rate, had himself all too little, most happily calls them in his Battle of the Books, - 'the two noblest of things, sweetness and light. ${ }^{83}$

Arnold's aim is not, in the proper sense, an elitist one: he believes that this cultuvation is the proper aim of us all.

This is the social idea; and the men of culture are the true apostles of equality. The great men of culture are those who have had a passion for diffusing, for making prevail, for carrying from one end of society to the other, the best knowledge, the best ideas of their time; who have laboured to divest knowledge of all that was harsh, uncouth, difficult, abstract, professional, exclusive; to humanise it, to make it efficient outside the clique of the cultivated and learned, yet still remaining the best knowledge and thought of the time, and a true source, therefore, of sweetness and light. ${ }^{84}$

If you have this view of culture, you will think of cultural geneticism as the doctrine of the ignorant or the lazy, or at least of those

${ }^{81}$ Arnold, Culture and Anarchy, p. 119.

${ }^{82}$ Ibid., p. 33.

${ }^{83}$ Ibid., p. 37.

${ }^{84}$ Ibid., p. 48. The phrase "sweetness of light" is from Jonathan Swift's Battle of the Books (1697). The contest between the ancients (represented there by the bee) and the moderns (represented by the spider) is won by the ancients, who provide, like the bee, both honey and wax - sweetness and light. Sweetness is, then, aesthetic, and light, intellectual, perfection. 
who pander to them. And it is a view of culture whose adoption would diminish any society that seriously adopted it.

Not only is the conflation of identities and cultures mistaken, but the view of cultural possession that underlies that error is the view of the Philistine, who, in Arnold's translation of Epictetus, makes

a great fuss about exercise, a great fuss about eating, a great fuss about drinking, a great fuss about walking, a great fuss about riding. All these things ought to be done merely by the way: the formation of the spirit and character must be our real concern. ${ }^{85}$

\subsection{Identities and Norms}

I have been exploring these questions about culture in order to show how unsatisfactory an account of the significance of race that mistakes identity for culture can be. But if this is the wrong route from identity to moral and political concerns, is there a better way?

$\mathrm{W}$ e need to go back to the analysis of racial identities. While the theories on which ascription is based need not themselves be normative, these identities come with normative as well as descriptive expectations; about which, once more, there may be both inconsistency in the thinking of individuals and fairly widespread disagreement among them. There is, for example, a very wide range of opinions among American Jews as to what their being Jewish commits them to; and while most Gentiles probably don't think about the matter very much, people often make remarks that suggest they admire the way in which, as they believe, Jews have "stuck together," an admiration that seems to presuppose the moral idea that it is, if not morally obligatory, then at least morally desirable for those who share identities to take responsibility for each other. (Similar comments have been made increasingly often about Korean-Americans.)

${ }^{85}$ Arnold, Culture and Anarchy, p. 36. 
W e need, in short, to be clear that the relations between identities and moral life are complex. In the liberal tradition, to which I adhere, we see public morality as engaging each of us as individuals with our individual "identities": and we have the notion, which comes (as Charles Taylor has rightly argued) from the ethics of authenticity, ${ }^{86}$ that, other things being equal, people have the right to be acknowledged publicly as what they already really are. It is because someone is already authentically Jewish or gay that we deny them something in requiring them to hide this fact, to "pass," as we say, for something that they are not. Taylor has suggested that we call the political issues raised by this fact the politics of recognition: a politics that asks us to acknowledge socially and politically the authentic identities of others.

As has often been pointed out, however, the way much discussion of recognition proceeds is strangely at odds with the individualist thrust of talk of authenticity and identity. If what matters about me is my individual and authentic self, why is there so much contemporary talk of identity about large categories - race, gender, ethnicity, nationality, sexuality — that seem so far from individual? What is the relation between this collective language and the individualist thrust of the modern notion of the self? How has social life come to be so bound up with an idea of identity that has deep roots in romanticism with its celebration of the individual over against society ${ }^{87}$

The connection between individual identity, on the one hand, and race and other collective identities, on the other, seems to be something like this: Each person's individual identity is seen as having two major dimensions. There is a collective dimension,

${ }^{86}$ Charles Taylor, Multiculturalism and "The Politics of Recognition," with commentary by Amy Gutmann (editor), K. Anthony Appiah, Jürgen Habermas, Steven C. Rockefeller, Michael Walzer, and Susan Wolf (Princeton, N.J.: Princeton University Press, 1994).

${ }^{87}$ Taylor reminds us rightly of Lionel Trilling's profound contributions to our understanding of this history. I discuss Trilling's work in chapter 4 of In My Father's House (New York: Oxford University Press, 1992). 
the intersection of their collective identities; and there is what I will call a personal dimension, consisting of other socially or morally important features of the person - intelligence, charm, wit, cupidity - that are not themselves the basis of forms of collective identity.

The distinction between these two dimensions of identity is, so to speak, a sociological rather than a logical distinction. In each dimension we are talking about properties that are important for social life. But only the collective identities count as social categories, kinds of person. There is a logical category but no social category of the witty, or the clever, or the charming, or the greedy: people who share these properties do not constitute a social group, in the relevant sense. The concept of authenticity is central to the connection between these two dimensions; and there is a problem in many current understandings of that relationship, a misunderstanding one can find, for example, in Charles Taylor's recent (brilliant) essay on Multiculturalism and "The Politics of Reconstruction."

\subsection{Authenticity}

Taylor captures the ideal of authenticity in a few elegant sentences: "There is a certain way of being that is $m y$ way. I am called upon to live my life in this way. ... If I am not [true to myself], I miss the point of my life." ${ }^{88}$ To elicit the problem here, let me start with a point Taylor makes in passing about Herder:

I should note here that Herder applied his concept of originality at two levels, not only to the individual person among other persons, but also to the culture-bearing people among other peoples. Just like individuals, a Volk should be true to itself, that is, its own culture. ${ }^{89}$

It seems to me that in this way of framing the issue less attention than necessary is paid to the connection between the originality

\footnotetext{
${ }^{88}$ Taylor, Multiculturalism, p. 30.

${ }^{89}$ Ibid., p. 31.
} 
of persons and of nations. After all, in many places nowadays, the individual identity, whose authenticity screams out for recognition, is likely to have an ethnic identity (which Herder would have seen as a national identity) as a component of its collective dimension. It is, among other things, my being, say, an African-American that shapes the authentic self that I seek to express. ${ }^{90}$ And it is, in part, because I seek to express my self that I seek recognition of an African-American identity. This is the fact that makes problems: for recognition as an African-American means social acknowledgment of that collective identity, which requires not just recognizing its existence but actually demonstrating respect for it. If, in understanding myself as African-American, I see myself as resisting white norms, mainstream American conventions, the racism (and, perhaps, the materialism or the individualism) of "white culture," why should I at the same time seek recognition from these white others?

There is, in other words, at least an irony in the way in which an ideal - you will recognize it if I call it the Bohemian ideal in which authenticity requires us to reject much that is conventional in our society is turned around and made the basis of a "politics of recognition."

Irony is not the Bohemian's only problem. It seems to me that this notion of authenticity has built into it a series of errors of philosophical anthropology. It is, first of all, wrong in failing to see, what Taylor so clearly recognizes, namely, the way in which the self is, as he says, dialogically constituted. The rhetoric of authenticity proposes not only that I have a way of being that is all my own, but that in developing it I must fight against the family, organized religion, society, the school, the state - all the forces of convention. This is wrong, however, not only because it is in dialogue with other people's understandings of who I am that I develop a conception of my own identity (Charles Taylor's point) but also because my identity is crucially constituted through con-

${ }^{90}$ And, for Herder, this would be a paradigmatic national identity. 
cepts (and practices) made available to me by religion, society, school, and state and mediated to varying degrees by the family (Hacking's point about "making up people"). Dialogue shapes the identity I develop as I grow up: but the very material out of which I form it is provided, in part, by my society, by what Taylor calls its language in "a broad sense." ${ }^{91}$ I shall borrow and extend Taylor's term "monological" here to describe views of authenticity that make these connected errors.

I used the example of Afro-Americans just now, and it might seem that this complaint cannot be lodged against an American black nationalism: African-American identity, it might be said, is shaped by African-American society, culture, and religion. "It is dialogue with these black others that shapes the black self; it is from these black contexts that the concepts through which AfricanAmericans shape themselves are derived. The white society, the white culture, over against which an African-American nationalism of the counter-conventional kind poses itself, is therefore not part of what shapes the collective dimension of the individual identities of black people in the United States."

This claim is simply wrong. And what shows it is wrong is the fact that it is in part a recognition of a black identity by "white society" that is demanded by nationalism of this form. And "recognition" here means what Taylor means by it, not mere acknowledgment of one's existence. African-American identity, as I have argued, is centrally shaped by American society and institutions: it cannot be seen as constructed solely within African-American communities. African-American culture, if this means shared beliefs, values, practices, does not exist: what exist are AfricanAmerican cultures, and though these are created and sustained in large measure by African-Americans, they cannot be understood without reference to the bearers of other American racial identities.

\footnotetext{
${ }^{91}$ The broad sense "cover[s] not only the words we speak, but also other modes of expression whereby we define ourselves, including the 'languages' of art, of gesture, of love, and the like" (p. 32).
} 
There is, I think, another error in the standard framing of authenticity as an ideal, and that is the philosophical realism (which is nowadays usually called "essentialism") that seems inherent in the way questions of authenticity are normally posed. Authenticity speaks of the real self buried in there, the self one has to dig out and express. It is only later, after romanticism, that the idea develops that one's self is something that one creates, makes up, so that every life should be an artwork whose creator is, in some sense, his or her own greatest creation. (This is, I suppose, an idea one of whose sources is Oscar Wilde; but it is surely very close to that self-cultivation that Arnold called "culture.")

Of course, neither the picture in which there is just an authentic nugget of selfhood, the core that is distinctively me, waiting to be dug out, nor the notion that I can simply make up any self I choose should tempt us. W e make up selves from a tool kit of options made available by our culture and society: in ways that I pointed out earlier. W e do make choices, but we don't determine the options among which we choose. ${ }^{92}$

If you agree with this, you will wonder how much of authenticity we should acknowledge in our political morality: and that will depend, I suppose, on whether an account of it can be developed that is neither essentialist nor monological.

It would be too large a claim that the identities that claim recognition in the multicultural chorus must be essentialist and monological. But it seems to me that one reasonable ground for suspicion of much contemporary multicultural talk is that the conceptions of collective identity they presuppose are indeed remarkably unsubtle in their understandings of the processes by which identities, both individual and collective, develop. The story I have told for African-American identity has a parallel for other collective identities: in all of them, I would argue, false theories play a central role in the application of the labels; in all of them

${ }^{92}$ This is also too simple: for reasons captured in Anthony Giddens's many discussions of "duality of structure." 
the story is complex, involves "making up people," and cannot be explained by an appeal to an essence.

\subsection{Beyond Identity}

The large collective identities that call for recognition come with notions of how a proper person of that kind behaves: it is not that there is one way that Blacks should behave, but that there are proper black modes of behavior. These notions provide loose norms or models, which play a role in shaping the life-plans of those who make these collective identities central to their individual identities; of the identifications of those who fly under these banners. ${ }^{93}$ Collective identities, in short, provide what we might call scripts: narratives that people can use in shaping their lifeplans and in telling their life stories. In our society (though not, perhaps, in the England of Addison and Steele) being witty does not in this way suggest the life-script of "the wit." And that is why what I called the personal dimensions of identity work differently from the collective ones.

This is not just a point about modern Westerners: crossculturally it matters to people that their lives have a certain narrative unity; they want to be able to tell a story of their lives that makes sense. The story - my story - should cohere in the way appropriate by the standards made available in my culture to a person of my identity. In telling that story, how I fit into the wider story of various collectivities is, for most of us, important. It is not just gender identities that give shape (through, for example, rites of passage into woman- or manhood) to one's life: ethnic and national identities, too, fit each individual story into a larger narrative. And some of the most "individualist" of individuals value such things. Thomas Hobbes spoke of the desire for glory as one of the dominating impulses of human beings, one that was bound

${ }^{93}$ I say "make" here, not because I think there is always conscious attention to the shaping of life-plans or a substantial experience of choice, but because I want to stress the anti-essentialist point that there are choices that can be made. 
to make trouble for social life. But glory can consist in fitting and being seen to fit into a collective history: and so, in the name of glory, one can end up doing the most social things of all.

How does this general idea apply to our current situation in the multicultural West? We live in societies in which certain individuals have not been treated with equal dignity because they were, for example, women, homosexuals, Blacks, Catholics. Because, as Taylor so persuasively argues, our identities are dialogically shaped, people who have these characteristics find them central — often, negatively central — to their identities. Nowadays there is a widespread agreement that the insults to their dignity and the limitations of their autonomy imposed in the name of these collective identities are seriously wrong. One form of healing of the self that those who have these identities participate in is learning to see these collective identities not as sources of limitation and insult but as a valuable part of what they centrally are. Because the ethics of authenticity requires us to express what we centrally are in our lives, they move next to the demand that they be recognized in social life as women, homosexuals, Blacks, Catholics. Because there was no good reason to treat people of these sorts badly, and because the culture continues to provide degrading images of them nevertheless, they demand that we do cultural work to resist the stereotypes, to challenge the insults, to lift the restrictions.

These old restrictions suggested life-scripts for the bearers of these identities, but they were negative ones. In order to construct a life with dignity, it seems natural to take the collective identity and construct positive life-scripts instead.

An African-American after the Black Power movement takes the old script of self-hatred, the script in which he or she is a "nigger," and works, in community with others, to construct a series of positive black life-scripts. In these life-scripts, being a Negro is recoded as being black: and this requires, among other things, refusing to assimilate to white norms of speech and be- 
havior. And if one is to be black in a society that is racist then one has constantly to deal with assaults on one's dignity. In this context, insisting on the right to live a dignified life will not be enough. It will not even be enough to require that one be treated with equal dignity despite being black: for that will require a concession that being black counts naturally or to some degree against one's dignity. And so one will end up asking to be respected as a Black.

I hope I seem sympathetic to this story. I am sympathetic. I see how the story goes. It may even be historically, strategically necessary for the story to go this way. ${ }^{94}$ But I think we need to go on to the next necessary step, which is to ask whether the identities constructed in this way are ones we can all be happy with in the longer run. What demanding respect for people as Blacks or as gays requires is that there be some scripts that go with being an African-American or having same-sex desires. There will be proper ways of being black and gay: there will be expectations to be met; demands will be made. It is at this point that someone who takes autonomy seriously will want to ask whether we have not replaced one kind of tyranny with another. If I had to choose between Uncle Tom and Black Power, I would, of course, choose the latter. But I would like not to have to choose. I would like other options. The politics of recognition requires that one's skin color, one's sexual body, should be politically acknowledged in ways that make it hard for those who want to treat their skin and their sexual body as personal dimensions of the self. And "personal" doesn't mean "secret" but "not too tightly scripted," "not too constrained by the demands and expectations of others."

In short, so it seems to me, those who see potential for conflict between individual freedom and the politics of identity are right.

${ }^{94}$ Compare what Jean-Paul Sartre wrote in his "Orphée Noir," in Anthologie de la Nouvelle Poésie Nègre et Malagache de Langue Française, ed. L. S. Senghor, p. xiv. Sartre argued, in effect, that this move is a necessary step in a dialectical progression. In this passage he explicitly argues that what he calls an "antiracist racism" is a path to the "final unity . . . the abolition of differences of race." 


\subsection{Why Differences between Groups Matter}

But there is a different kind of worry about racial identities; one that has to do not with their being too-tightly scripted but with a consequence of their very existence for social life. We can approach the problem by asking why differences between groups matter.

This is, I think, by no means obvious. If some minority groups - Korean-Americans, say - do especially well, most people feel, more power to them. We worry, then, about the minorities that fail. And the main reason why people currently worry about minorities that fail is that group failure may be evidence of injustice to individuals. That is the respectable reason why there is so much interest in hypotheses, like those of Murray and Herrnstein, that suggest a different diagnosis. But let us suppose that we can get rid of what we might call Sowellian discrimination: discrimination based on false or even unwarranted beliefs about the different average capacities of racial groups. ${ }^{95}$

Even without Sowellian discrimination socioeconomic disparities between groups threaten the fairness of our social arrangements. This issue can be kept clear only if we look at the matter from the point of view of an individual. Suppose I live in a society with two groups, Blacks and Whites. Suppose that, for whatever reason, the Black group, to which I obviously belong, scores averagely low on a test that is genuinely predictive of job-performance. Suppose the test is expensive. And suppose I would have, in fact, a high score on this test, and that I would, in fact, perform well. ${ }^{96}$

\footnotetext{
95 "Once the possibility of economic performance differences between groups is admitted, then differences in income, occupational 'representation,' and the like do not, in themselves, imply that decision-makers took race or ethnicity into account. However, in other cases, group membership may in fact be used as a proxy for economically meaningful variables, rather than reflecting either mistaken prejudices or even subjective affinities and animosities" (Sowell, Race and Culture, p. 114).

${ }^{96}$ You need both of these conditions, because a high score on a test that correlates well for some skill doesn't necessarily mean you will perform well. And, in fact, Sowell discusses the fact that the same IQ score predicts different levels of economic success for different ethnic groups (Race and Culture, pp. 173, 182).
} 
In these circumstances, it may well be economically rational for an employer, knowing what group I belong to, simply not to give me the test and, thus, not to hire me. ${ }^{97}$ The employer has acted in a rational fashion; there is no Sowellian discrimination here. But most people will understand me if I say that I feel that this outcome is unfair. One way of putting the unfairness is to say: what I can do and be with my talents is being held back became others, over whose failings I have no control, happen to have the characteristics they do.

Capitalism - like life - is full of such unfairness: luck from lotteries to hurricanes - affects profit. And we can't get rid of all unfairness; for if we had perfect insurance, zero risk, there'd be no role for entrepreneurship, no markets, no capitalism. But we do think it proper to mitigate some risks. We think, for example, that we should do something about bad luck when it has large negative effects on individual people, or if it forces them below some socioeconomic baseline - we insure for car accidents, death, loss of home; the government helps those ruined by largescale acts of God. W e don't worry much about the chance production of small negative effects on individuals, even large numbers of individuals.

It is at least arguable that, in our society, the cost to competent, well-behaved individual Blacks and Hispanics ${ }^{98}$ of being constantly treated as if they have to measure up — the cost in stress, in anger, in lost opportunities - is pretty high..$^{99}$ It would be consistent with a general attitude of wanting to mitigate risks with large negative consequences for individuals to try to do something about it. ${ }^{100}$

\footnotetext{
${ }^{97}$ Knowing this, I might offer to pay myself, if I had the money: but that makes the job worth less to me than to members of the other groups. So I lose out again.

${ }^{98}$ Let me explicitly point out that many of these people are not middle class.

${ }^{99}$ I actually think that there is still rather more Sowellian discrimination than Sowell generally acknowledges; but that is another matter.

${ }^{100}$ It will seem to some that I've avoided an obvious argument here, which is that the inequalities in resources that result from differences in talents under capi-
} 
This specific sort of unfairness - where a person who is atypically competent in a group that is averagely less competent - is the result, among other things, of the fact that jobs are allocated by a profit-driven economy and the fact that I was born into a group in which I am atypical. The latter fact may or may not be the consequence of policies adopted by this society. Let's suppose it isn't: so society isn't, so to speak, causally responsible. According to some - for example, Thomas Sowell, again — that means it isn't morally responsible either: you don't have to fix what you didn't break.

I'm not so sure. First, we can take collective responsibility, "as a society," for harms we didn't cause, as is recognized in the Americans with Disabilities Act. But second, the labor market is, after all, an institution: in a modern society it is kept in place by such arrangements as the laws of contract, the institution of money, laws creating and protecting private property, health, and safety at work, and equal employment laws. Sowell may disapprove of some of these, but he can't disapprove of all of them; without all of them, there'd be no capitalism. So the outcome is the result not only of my bad luck but of its interaction with social arrangements, which could be different.

Thus, once we grasp the unfairness of this situation, people might feel that something should be done about it. One possible thing would be to try to make sure there were no ethnic minorities significantly below norm in valuable skills. If the explanation for most significant differences between groups is not hereditary, this could be done, in part, by adopting policies that discouraged significant ethnic differentiation, which would gradually produce assimilation to a single cultural norm. Or it could be done by devoting resources most actively to the training of members of disadvantaged groups.

talism need addressing. I agree. But the argument I am making here is meant to appeal to only extremely unradical individualist ideas; it's designed not to rely on arguing for egalitarian outcomes directly. 
Another - more modest - move would be to pay special attention to finding talented members of minority groups who would not be found when employers were guided purely by profit.

A third - granted once more that the differences in question are not largely hereditary - would be to explore why there are such differences and to make known to people ways of giving themselves or their children whatever aptitudes will maximize their life-changes, given their hereditary endowments.

Fourth, and finally, for those differences that were hereditary it would be possible to do research to seek to remedy the initial distribution by the genetic lottery — as we have done in making it possible for those without natural resistance to live in areas where malaria and yellow fever are endemic.

Each of these strategies would cost something and the costs would be not only financial. Many people believe that the global homogenization of culture impoverishes the cultural fabric of our lives. It is a sentiment, indeed, we find in Arnold:

My brother Saxons have, as is well known, a terrible way with them of wanting to improve everything but themselves off the face of the earth; I have no passion for finding nothing but myself everywhere; I like variety to exist and to show itself to me, and I would not for the world have the lineaments of the Celtic genius lost. ${ }^{101}$

The first strategy — of cultural assimilation — would undoubtedly escalate that process. And all of these strategies would require more knowledge than we now have to apply in actual cases so as to guarantee their success. Anyone who shares my sense that there is an unfairness here to be met, an unfairness that has something to do with the idea that what matters is individual merit, should be interested in developing that kind of knowledge.

But I want to focus for a moment on the general effect of these four strategies. They would all lead to producing a population

${ }^{101}$ Arnold, Celtic Literature, p. 11. 
less various in some of the respects that make a difference to major socioeconomic indicators. This would not mean that everybody would be the same as everybody else - but it could lead to a more recreational conception of racial identity. It would make AfricanAmerican identity more like Irish-American identity for most of those who care to keep the label. And that would allow us to resist one persistent feature of ethno-racial identities: they risk becoming the obsessive focus, the be-all and end-all, of the lives of those who identify with them. They lead people to forget that their individual identities are complex and multifarious - that they have enthusiasms that do not flow from their race or ethnicity, interests and tastes that cross ethno-racial boundaries, that they have occupations or professions, are fans of clubs and groups. And they then lead them, in obliterating the identities they share with people outside their race or ethnicity, away from the possibility of identification with others. Collective identities have a tendency, if I may coin a phrase, to "go imperial," dominating not only people of other identities, but the other identities, whose shape is exactly what makes each of us what we individually and distinctively are.

In policing this imperialism of identity - an imperialism as visible in racial identities as anywhere else - it is crucial to remember always that we are not simply black or white or yellow or brown, gay or straight or bisexual, Jewish, Christian, Muslim, Buddhist, Confucian: but that we are also brothers and sisters; parents and children; liberals, conservatives, and leftists; teachers and lawyers and auto-makers and gardeners; fans of the Padres and the Bruins; amateurs of grunge rock and lovers of Wagner; movie-buffs; MTV-holics; mystery-readers; surfers and singers; poets and pet-lovers; students and teachers; friends and lovers. Racial identity can be the basis of resistance to racism; but even as we struggle against racism - and though we have made great progress, we have further still to go - let us not let our racial identities subject us to new tyrannies. 


\subsection{In Conclusion}

Much of what I have had to say in this essay will, no doubt, seem negative. It is true that I have defended an analytical notion of racial identity, but I have gone on to worry about too hearty an endorsement of racial identification. Let me quote Matthew Arnold again, for the last time:

I thought, and I still think, that in this [Celtic] controversy, as in other controversies, it is most desirable both to believe and to profess that the work of construction is the fruitful and important work, and that we are demolishing only to prepare for it. ${ }^{102}$

So here are my positive proposals: live with fractured identities; engage in identity play; find solidarity, yes, but recognize contingency, and, above all, practice irony. ${ }^{103}$ In short I have only the proposals of a banal "postmodernism." And there is a regular response to these ideas from those who speak for the identities that now demand recognition, identities toward which so many people have struggled in dealing with the obstacles created by sexism, racism, homophobia. "It's all very well for you. You academics live a privileged life; you have steady jobs; solid incomes; status from your place in maintaining cultural capital. Trifle with your own identities, if you like; but leave mine alone."

To which I answer only: My job as an intellectual is to call it as I see it. I owe my fellow-citizens respect, certainly, but not a feigned acquiescence. I have a duty to reflect on the probable consequences of what I say; and then, if I still think it worth saying, to accept responsibility for it. If I am wrong, I say, you do not need to plead that I should tolerate error for the sake of human liberation; you need only correct me. But if I am right, so it seems to me, there is a work of the imagination that we need to begin.

102 Ibid., p. ix.

103 See, for example, Richard Rorty, Contingency, Irony and Solidarity (New York: Cambridge University Press, 1989), and my review of it: "Metaphys Ed.," Village Voice, September 19, 1989, 55. 
And so I look forward to taking up, along with others, the fruitful imaginative work of constructing collective identities for a democratic nation in a world of democratic nations; work that must go hand in hand with cultivating democracy here and encouraging it everywhere else. About the identities that will be useful in this project, let me say only this: the identities we need will have to recognize both the centrality of difference within human identity and the fundamental moral unity of humanity. 